Article

\title{
Vanadium Supported on Alumina and/or Zirconia Catalysts for the Selective Transformation of Ethane and Methanol
}

\author{
Souhila Benomar ${ }^{1,2}$, Amada Massó $^{1}$, Benjamín Solsona ${ }^{3}$, Rachid Issaadi $^{2}$ and \\ Jose M. López Nieto ${ }^{1, * \text { (iD }}$ \\ 1 Instituto de Tecnología Química, Universitat Politècnica de València-Consejo Superior de Investigaciones \\ Científicas, Avenida de los Naranjos s/n, 46022 Valencia, Spain; benosouh06@yahoo.fr (S.B.); \\ masso.amada@gmail.com (A.M.) \\ 2 Laboratoire des Applications Energétiques de l'Hydrogène, Faculté de Technologie, Université Saad Dahlab, \\ Blida 1, Blida 09000, Algeria; rachidissaadi@yahoo.fr \\ 3 Department of Chemical Engineering, Universitat de València, Av. Universitat s/n, 46100 Burjassot, Spain; \\ bensoles@yahoo.es \\ * Correspondence: jmlopez@itq.upv.es; Tel.: +34-96-387-7808
}

Received: 2 February 2018; Accepted: 19 March 2018; Published: 22 March 2018

\begin{abstract}
Vanadium supported on pure $\left(\mathrm{Al}_{2} \mathrm{O}_{3}, \mathrm{ZrO}_{2}\right)$ or mixed zirconia-alumina (with $\mathrm{Al} /(\mathrm{Al}+\mathrm{Zr})$ ratio of 0.75 or 0.25 ) catalysts have been prepared by wet impregnation, using homemade prepared supports. The catalysts have been characterized and tested in the oxidative dehydrogenation (ODH) of ethane and in the methanol aerobic transformation. The catalytic performance strongly depends on the nature of the metal oxide support. Thus, activity decreases in the order: $\mathrm{VOx} / \mathrm{ZrO}_{2}>$ $\mathrm{VOx} /(\mathrm{Al}, \mathrm{Zr}$-oxides $)>\mathrm{VOx} / \mathrm{Al}_{2} \mathrm{O}_{3}$. On the other hand, at low and medium ethane conversions, the selectivity to ethylene presents an opposite trend: $\mathrm{VOx} / \mathrm{Al}_{2} \mathrm{O}_{3}>\mathrm{VOx} /(\mathrm{Al}, \mathrm{Zr}$-oxides $)>\mathrm{VOx} / \mathrm{ZrO}_{2}$. The different selectivity to ethylene at high conversion is due to the lower/higher initial ethylene formation and to the extent of the ethylene decomposition. Interestingly, $\mathrm{VOx} /(\mathrm{Al}, \mathrm{Zr}$-oxides) with low Zr-loading present the lowest ethylene decomposition. The catalytic results obtained mainly depend on the nature of the supports whereas the role of the dispersion of vanadium species is unclear. In methanol oxidation, the catalysts tested present similar catalytic activity regardless of the support $\left(\mathrm{Al}_{2} \mathrm{O}_{3}, \mathrm{ZrO}_{2}\right.$ or mixed $\left.\mathrm{Al}_{2} \mathrm{O}_{3}-\mathrm{ZrO}_{2}\right)$ but strong differences in the selectivity to the reaction products. Thus, dimethyl ether was mainly observed on alumina-supported vanadium oxide catalysts (which is associated to the presence of acidic sites on the surface of the catalyst, as determined by TPD-NH$H_{3}$ ). Formaldehyde was the main reaction product on catalysts supported on $\mathrm{Zr}$-containing oxides (which can be related to a low presence of acid sites). In this article, the importance of the presence of acid sites in ethane $\mathrm{ODH}$, which can be estimated using the methanol transformation reaction, is also discussed.
\end{abstract}

Keywords: ODH of ethane; ethylene; methanol transformation; formaldehyde; dimethyl ether; vanadium; zirconia; alumina

\section{Introduction}

Ethylene is, probably, the most important raw material used in petrochemistry. In fact, the crisis of the last decade did not affect the ethane demand and the global capacity has been continuously increasing. Currently, more than $95 \%$ of the ethylene produced around the world proceeds from the steam cracking process, an easy, but inefficient, non-catalytic process. Steam cracking presents low energetic efficiency and low selectivity to the desired compounds. Therefore, new alternatives to 
sort out these problems are under study. Probably, the most promising alternative is the oxidative dehydrogenation of ethane (ODH of ethane), an exothermic reaction in which ethane is fed together with oxygen. In this reaction, using standard catalytic systems the catalysts hardly deactivates as a continuous re-activation of the active sites by the oxygen fed takes place. Moreover, only a few by-products, which are easy to be separated, are formed. Unfortunately, the oxidative dehydrogenation of ethane has not been implemented yet in industry. Nevertheless, there are promising results at the laboratory scale that make this reaction very interesting to study.

Among the catalytic systems reported in the literature (including patents) in the oxidative dehydrogenation of ethane, there are four groups that are especially interesting: (i) supported vanadium oxide catalysts [1-27]; (ii) promoted and supported nickel oxide catalysts [4,11,28-32]; (iii) MoVTe(Sb) multicomponent oxides presenting an orthorhombic bronze structure (M1 phase) [1,2,11,33,34]; and (iv) catalysts based on non-reducible metal oxides [11,35]. In the present article we will focus on the first group.

Vanadium oxide based catalysts are well known and extensively employed in industry for the gas phase heterogeneous oxidation and ammoxidation of hydrocarbons [1-4] and for the oxidative dehydrogenation of short chain alkanes, including ethane [4-12]. Supported vanadium oxide catalysts have been considered for many years the most promising catalysts in the ODH of $\mathrm{C}_{2}-\mathrm{C}_{4}$ alkanes [4-14], although the nature of the optimal support is different depending on the nature of the alkane fed $[5-7,14,15]$. The catalytic behavior of supported vanadia catalysts can be related to $[5-7,13-27]$ : (i) the nature of $\mathrm{V}^{\mathrm{n}+}-\mathrm{O}$ species, i.e., coordination, aggregation and oxidation state of V-species; (ii) the redox properties of the catalysts, i.e., the $\mathrm{V}^{5+} / \mathrm{V}^{4+}$ ratio in reaction conditions, which are influenced by the presence of promoters and the nature of the metal oxide support; and (iii) the acid-base character of the catalysts (and support), which strongly influences the adsorption of reactants and the desorption of partial oxidation products and finally determines the selectivity to olefins. Depending on the support material and the VOx concentration, supported vanadium oxide can exist as isolated tetrahedral monovanadates, one or two-dimensional polyvanadate domains, or bulk $\mathrm{V}_{2} \mathrm{O}_{5}$ crystallites $[5-7,12,23]$.

$\mathrm{Al}_{2} \mathrm{O}_{3}$ seem to be one of the most effective support for vanadium in the ODH of ethane [5-24] as it presents relatively high acidity, which seems to be beneficial in this reaction in contrast with the ODH of propane and n-butane [5-7,12]. It seems that the acidity of the support could favor the ethylene desorption from the surface of the catalyst, thus, increasing the selectivity to ethylene [21].

$\mathrm{ZrO}_{2}$ has received considerable attention in catalysis and material science, not only as a promising catalyst for a number of reactions, but also as a support. Thus, zirconia has bifunctional properties as an acid and as a base, and high thermal stability. More interestingly $\mathrm{ZrO}_{2}$ [25] and $\mathrm{Al}_{2} \mathrm{O}_{3}-\mathrm{ZrO}_{2}$ [26,27] are appropriate supports for the synthesis of highly dispersed VOx-species. As highly-isolated vanadium species tend to overoxidize ethylene to a lower extent than more aggregated species [5-11] we have thought that by modifying the alumina support through the addition of zirconia, the ethylene decomposition could be mitigated. Moreover, the oxygen species bridging surface vanadium oxide species to the support may play a significant role in catalyst activity. Thus, a change in the support modifies the V-O-Support bond and consequently the catalytic performance. Thus, the reaction rate for ethane oxidation varies in the sequence $\mathrm{TiO}_{2}>\mathrm{ZrO}_{2}>>\mathrm{Al}_{2} \mathrm{O}_{3}>\mathrm{Nb}_{2} \mathrm{O}_{5}>\mathrm{CeO}_{2}-\mathrm{SiO}_{2}$ [13].

The selective transformation of methanol in the presence of oxygen is a very interesting reaction that can lead to the formation of highly valuable compounds such as formaldehyde $\left(\mathrm{CH}_{2} \mathrm{O}\right)$ and /or dimethylether (DME, $\mathrm{CH}_{3} \mathrm{OCH}_{3}$ ) depending on the characteristics of catalysts and/or the reaction conditions. However, in addition, this reaction can be also used for determining, in "in-situ" conditions, the acid and redox nature of catalytically active sites of catalysts [3,36-38]. One advantage of methanol compared to other molecules is its high sensitivity to the nature of the surface active sites. Thus, when working at low methanol conversion the formaldehyde formation is associated to the presence of redox sites (which seems to be also active in the oxidative dehydrogenation of alkanes), whereas the dimethylether is formed by methanol dehydration that takes place in presence of Lewis and 
Brønsted acid sites. Since, in our case, the catalytic performance of supported vanadium oxide catalysts (in terms of selectivity) seems to be related to both redox and acid characteristics of catalysts, it could be interesting to study in parallel the catalytic performance of some of the most interesting catalysts in both ethane ODH and in the aerobic transformation of methanol. According to Tatibouet [36], the selectivity pattern in methanol transformation and the formation rates of the reaction products can be used to characterize both structural (dispersion), as well as chemical properties (acid-base and redox) of supported oxide catalysts. Thus, methanol transformation can be summarized into three principal reactions [36-39]: (i) oxidation reactions which need oxygen (molecular or supplied by the catalyst), involving the formation of formaldehyde, formic acid and carbon oxides; (ii) dehydration reactions, which do not need oxygen, carried out by acid catalysts which are involved in the formation of DME; and (iii) both redox and acid reactions, involved in the formation of dimethoxymethane and methyl formate. Several metal oxides, including supported vanadium oxides catalysts, have been studied for methanol oxidation [4,36-39]. In addition, a comparison between catalytic performance for oxidation of methanol [39-43] or ethanol [44] and propane ODH has been reported in the last years. More recently, it has been reported that the use of methanol adsorption/desorption followed by in situ DRIFTS could be of interest in order to determine the concentration of active sites in $\mathrm{Nb}$-doped nickel oxide catalysts, which are very selective in the ethane ODH [29]. Accordingly, it could be also of interest to carry out a parallel study on both the methanol selective aerobic transformation and the ethane ODH over supported vanadium oxide catalysts.

Alumina-supported vanadia catalysts modified with other metal oxides, such as Cr, Mo, or W, have been studied for the oxidative transformation of methanol [45,46]. According to their results, modifiers can cover the support acidic surface sites, without modification of the surface vanadia redox product yield. So, the use of methanol aerobic transformation could be of interest to study (in reaction conditions) the characteristics of the surface of catalysts in term of activity, but also selectivity when considering the acid/redox ratio in catalysts, since the presence of acid sites (and the DME formation in these catalysts) seems to be in a parallel behavior [47].

As alumina is one of the preferred supports of vanadium oxide for the oxidative dehydrogenation of ethane, we have thought that a modification of $\mathrm{VOx} / \mathrm{Al}_{2} \mathrm{O}_{3}$ catalysts by the partial replacement of alumina by zirconia, oxide with redox characteristics, could lead to a positive effect as this reaction proceeds by a redox Mars-Van Krevelen mechanism. Then, the objective of this work is to study the catalytic performance of vanadium oxides supported on $\mathrm{Al}_{2} \mathrm{O}_{3}$ and / or $\mathrm{ZrO}_{2}$ supports as catalysts for the ODH of ethane. In this way, several V-contents (from 1 to $12 \mathrm{wt} \%$, depending on the surface area of support) and different metal oxides supports (i.e., $\mathrm{Al}_{2} \mathrm{O}_{3}, \mathrm{ZrO}_{2}$, and mixed $\mathrm{Al}-\mathrm{Zr}$ oxides) have been synthesized and characterized. Additionally, the selective aerobic transformation of methanol on these catalysts has also been studied in order to evaluate, in reaction conditions, the possible role of redox and acid sites in the ODH of ethane.

\section{Results and Discussion}

\subsection{Characterization of Catalysts}

Table 1 summarizes the main physicochemical characteristics of the catalysts synthesized. The metal oxide supports correspond to $\mathrm{Al}_{2} \mathrm{O}_{3}$ (named as $\mathrm{AC}$ ), $\mathrm{ZrO}_{2}-\mathrm{Al}_{2} \mathrm{O}_{3}$ mixed metal oxides, with a $\mathrm{Al} /\left(\mathrm{Al}+\mathrm{Zr}\right.$ ) atomic ratio of 0.75 (named as $\mathrm{BC}$ ) or 0.25 (named as $\mathrm{CC}$ ), and $\mathrm{ZrO}_{2}$ (named as DC).

$\mathrm{X}$-ray Diffraction (XRD) patterns of the supports (Figure 1) suggest that the AC material present $\gamma-\mathrm{Al}_{2} \mathrm{O}_{3}$ as the only crystalline phase (broad reflections at $2 \theta=37.1^{\circ}, 46.0^{\circ}$ and $66^{\circ}$ ) [48]. In the case of materials with $\mathrm{Al} /(\mathrm{Al}+\mathrm{Zr})$ atomic ratios of 0.75 or 0.25 (i.e., $\mathrm{BC}$ and $\mathrm{CC}$ supports, respectively), new broad reflections are also observed at $2 \theta=30.16^{\circ}$ and $50.65^{\circ}$ (their intensities increasing when increasing the $\mathrm{Zr}$-content), which indicate the appearance of $\mathrm{ZrO}_{2}$ crystallites with tetragonal symmetry. However, zirconia support (DC) is a mixture of monoclinic $\mathrm{m}-\mathrm{ZrO}_{2}$ (JCPDS file: $37-1484$ ) and tetragonal $\mathrm{t}-\mathrm{ZrO}_{2}$ (JCPDS file: 27-997) phases [49,50]. 
Table 1. Characteristics of the vanadium supported catalysts prepared by impregnation and activated at $550{ }^{\circ} \mathrm{C} / 5 \mathrm{~h}$ in air $^{\mathrm{a}}$.

\begin{tabular}{|c|c|c|c|c|c|}
\hline \multirow[t]{2}{*}{ Catalyst } & \multirow{2}{*}{$\frac{S_{\text {BET }}}{\left(\mathrm{m}^{2} / \mathrm{g}\right)}$} & \multirow[t]{2}{*}{ Support } & \multirow{2}{*}{$\frac{\text { V-Loading }}{\text { (wt } \% \text { V-Atoms) }^{b}}$} & \multicolumn{2}{|c|}{ TPR-Experiments } \\
\hline & & & & $\operatorname{TMC}\left({ }^{\circ} \mathrm{C}\right)^{\mathrm{C}}$ & $\begin{array}{c}\mathrm{H}_{2} \text {-Uptake } \\
\left(\mathrm{mmol}_{\mathrm{H} 2} / \mathrm{g}_{\text {cat }}\right) \\
\mathrm{d}\end{array}$ \\
\hline $4 \mathrm{AC}$ & 136 & $\mathrm{Al}_{2} \mathrm{O}_{3}$ & $4(0.53)$ & 478 & 0.5 \\
\hline $8 \mathrm{AC}$ & 159 & $\mathrm{Al}_{2} \mathrm{O}_{3}$ & $8(0.83)$ & 470 & 0.6 \\
\hline $12 \mathrm{AC}$ & 115 & $\mathrm{Al}_{2} \mathrm{O}_{3}$ & $12(1.61)$ & 597 & 2.0 \\
\hline $4 \mathrm{BC}$ & 177 & $\mathrm{Al}-\mathrm{Zr}-\mathrm{O}(\mathrm{Al} / \mathrm{Zr}=75 / 25)$ & $4(0.41)$ & 454 & 0.6 \\
\hline $8 B C$ & 143 & $\mathrm{Al}-\mathrm{Zr}-\mathrm{O}(\mathrm{Al} / \mathrm{Zr}=75 / 25)$ & $8(0.93)$ & 477 & 3.7 \\
\hline $2 \mathrm{CC}$ & 88 & $\mathrm{Al}-\mathrm{Zr}-\mathrm{O}(\mathrm{Al} / \mathrm{Zr}=25 / 75)$ & $2(0.43)$ & 461 & 0.5 \\
\hline $4 C C$ & 46 & $\mathrm{Al}-\mathrm{Zr}-\mathrm{O}(\mathrm{Al} / \mathrm{Zr}=25 / 75)$ & $4(1.57)$ & 420 & 0.5 \\
\hline $8 C C$ & 45 & $\mathrm{Al}-\mathrm{Zr}-\mathrm{O}(\mathrm{Al} / \mathrm{Zr}=25 / 75)$ & $8(1.95)$ & $409 / 602$ & 0.5 \\
\hline $12 \mathrm{CC}$ & 70 & $\mathrm{Al}-\mathrm{Zr}-\mathrm{O}(\mathrm{Al} / \mathrm{Zr}=25 / 75)$ & $12(2.66)$ & $426 / 605$ & 1.5 \\
\hline $1 \mathrm{DC}$ & 34 & $\mathrm{ZrO}_{2}$ & $1(0.57)$ & 392 & 0.2 \\
\hline $2 \mathrm{DC}$ & 33 & $\mathrm{ZrO}_{2}$ & $2(1.13)$ & 391 & 0.3 \\
\hline $4 \mathrm{DC}$ & 24 & $\mathrm{ZrO}_{2}$ & $4(2.85)$ & 379 & 0.8 \\
\hline $8 \mathrm{DC}$ & 28 & $\mathrm{ZrO}_{2}$ & $8(4.73)$ & $396 / 583$ & 2.2 \\
\hline $12 \mathrm{DC}$ & 23 & $\mathrm{ZrO}_{2}$ & $12(8.11)$ & 573 & 1.8 \\
\hline
\end{tabular}

a The metal oxide supports correspond to $\mathrm{Al}_{2} \mathrm{O}_{3}$ (named as $\mathrm{AC}$ ), $\mathrm{ZrO}_{2}-\mathrm{Al}_{2} \mathrm{O}_{3}$ mixed metal oxides, with a $\mathrm{Al} /\left(\mathrm{Al}+\mathrm{Zr}\right.$ ) atomic ratio of 0.75 (named as $\mathrm{BC}$ ) or 0.25 (named as $\mathrm{CC}$ ), and $\mathrm{ZrO}_{2}$ (named as DC). ${ }^{\mathrm{b}}$ V-loading: in $\mathrm{wt} \%$ of $\mathrm{V}$ atoms and, in parenthesis, in $10^{2}$ mmolv $\mathrm{m}^{-2}$; ${ }^{\mathrm{c}}$ temperature of the main maximum in the temperature-programmed reduction (TPR) profiles; ${ }^{\mathrm{d}}$ for $1 \mathrm{wt} \% \mathrm{~V}$, the reduction from $\mathrm{V}^{5+}$ to $\mathrm{V}^{3+}$ consumes $0.2 \mathrm{mmol}_{\mathrm{H} 2}\left(\mathrm{~g}_{\mathrm{cat}}\right)^{-1}$.
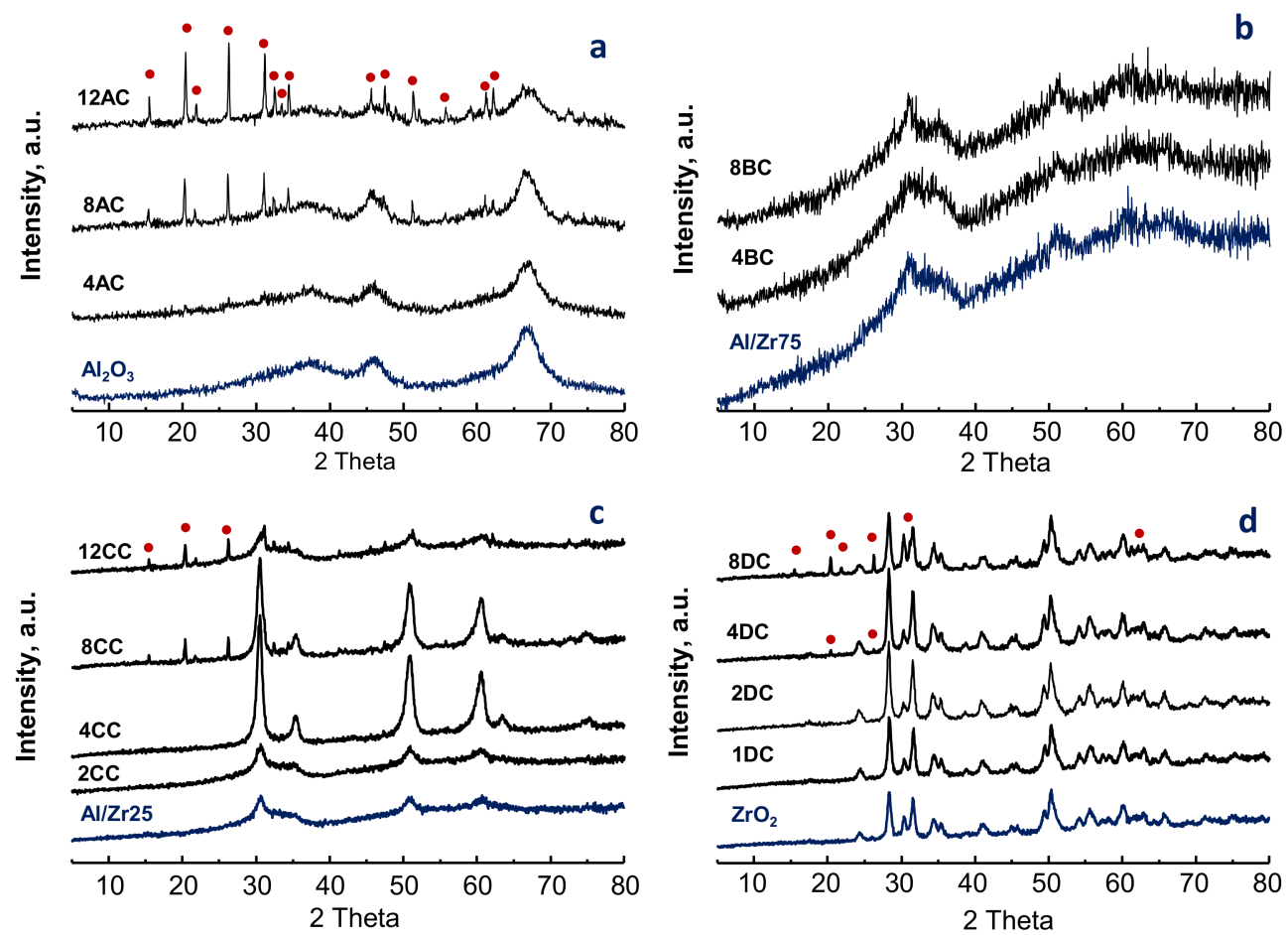

Figure 1. X-ray Diffraction (XRD) patterns of 4 sets of catalysts prepared by wet impregnation varying the amount of vanadium over different supports: (a) supported on $\mathrm{Al}_{2} \mathrm{O}_{3}$ (AC-series), with loadings of 4 (4AC), 8 (8AC), and $12 \mathrm{wt} \%$ of $\mathrm{V}$-atoms (12AC); (b) supported on $\mathrm{Al} / \mathrm{Zr}$-mixed oxide, $\mathrm{Al} / \mathrm{Zr}=75 / 25$ (BC-series), with loadings of 4 (4BC), and $8 \mathrm{wt} \%$ of $\mathrm{V}$-atoms $(8 \mathrm{BC})$; (c) supported $\mathrm{Al} / \mathrm{Zr}$-mixed oxide, $\mathrm{Al} / \mathrm{Zr}=25 / 75$ (CC-series), with loadings of 2 (2CC), 4 (4CC), 8 (8CC), and $12 \mathrm{wt} \%$ of $\mathrm{V}$-atoms (12CC); and (d) supported on $\mathrm{ZrO}_{2}$ (DC-series), with loading of 1 (1DC), 2 (2DC), 4 (4DC), 8 (8DC), and $12 \mathrm{wt} \%$ of V-atoms (12DC). Symbols: $(\bullet) \mathrm{V}_{2} \mathrm{O}_{5}$ (JCPDS: 41-1426). Name of catalysts as in Table 1. 
Figure 1 shows also the XRD patterns of supported vanadium oxide catalysts with different V-loadings. In the case of $\mathrm{Al}_{2} \mathrm{O}_{3}$-supported vanadium oxide catalysts, i.e., AC-series (Figure 1a), the characteristic peaks of $\gamma-\mathrm{Al}_{2} \mathrm{O}_{3}$ (broad reflections at $2 \theta=37.1^{\circ}, 46.0^{\circ}$ and $66.6^{\circ}$ ) can be seen for the $\mathrm{V}$-free sample and the sample with low V-loadings (i.e., $\mathrm{Al}_{2} \mathrm{O}_{3}$ and $4 \mathrm{AC}$ ). In addition to these, new peaks at $2 \theta=15.3^{\circ}, 20.3^{\circ}, 26.2^{\circ}, 31.2^{\circ}, 34.3^{\circ}$, and $47.3^{\circ}$ are also observed for samples with high V-loading (Figure 1a, patterns 8AC and 12AC) which can be related to the presence of orthorhombic $\mathrm{V}_{2} \mathrm{O}_{5}$ (JCPDS: 41-1426) [51].

In the case of catalysts supported on $\mathrm{Al}, \mathrm{Zr}$-oxide with low $\mathrm{Zr}$-loading (BC series) (Figure 1b), it can be observed the presence of broad diffraction peaks at $2 \theta=30^{\circ}, 50.7^{\circ}$ and $61.0^{\circ}$, which is related to tetragonal $\mathrm{t}-\mathrm{ZrO}_{2}$ (JCPDS file: 79-1976). However no peaks related to $\mathrm{V}_{2} \mathrm{O}_{5}$ have been detected for catalysts with V-loadings of 4 and $8 \mathrm{wt} \%$, suggesting a better dispersion of vanadium atoms on this support that in the $\mathrm{Zr}$-free alumina catalysts.

A different behavior is observed for the catalysts supported on $\mathrm{Al}, \mathrm{Zr}$-oxide with high $\mathrm{Zr}$-loading (CC-series) (Figure 1c). Thus, diffraction peaks at $2 \theta=30^{\circ}, 50.7^{\circ}$ and $61.0^{\circ}$ (related to tetragonal $\mathrm{t}-\mathrm{ZrO}_{2}$ (JCPDS card No. 79-1976) [49]) are observed. Moreover, peaks related to $\mathrm{V}_{2} \mathrm{O}_{5}$ crystallites have been also observed in catalysts with V-loading of $8 \mathrm{wt} \%$ and higher.

In $\mathrm{ZrO}_{2}$-supported vanadium oxide catalysts (DC-series), it can be seen the presence of both monoclinic and tetragonal $\mathrm{ZrO}_{2}$ and $\mathrm{V}_{2} \mathrm{O}_{5}$ crystallites in the sample with highest V-loading, i.e., 8DC sample (Figure 1d). Moreover, the presence of mixed $\mathrm{Zr}-\mathrm{V}$ oxides, as $\mathrm{ZrV}_{2} \mathrm{O}_{7}$ (JCPDS file: 16-0422), cannot be ruled out in the case of sample 8DC [50,52].

Raman spectroscopy has been also used in order to study the presence of non-crystalline phases, as well as the presence/absence of $\mathrm{V}_{2} \mathrm{O}_{5}$ crystallites with low crystal sizes. Figure 2 presents the Raman spectra of supported vanadium oxide catalysts. In the case of $\mathrm{Al}_{2} \mathrm{O}_{3}$-supported catalysts (Figure 2a), all spectra show the presence of characteristics bands related to $\mathrm{V}_{2} \mathrm{O}_{5}$, i.e., $994,702,697,527,404,284$, and $146 \mathrm{~cm}^{-1}[50,51]$. However, a broad band is also observed at ca. $900 \mathrm{~cm}^{-1}$ related to polymeric vanadium species. Different Raman spectra are observed in the case of samples supported on $\mathrm{Al}$ and $\mathrm{Zr}$ oxides with low $\mathrm{Zr}$-content (BC-series) (Figure $2 \mathrm{~b}$ ). Thus, in addition to bands of $\mathrm{V}_{2} \mathrm{O}_{5}$, relatively intense broad bands are also observed at ca. $900 \mathrm{~cm}^{-1}$ and at $1020 \mathrm{~cm}^{-1}$, related to polymeric $\mathrm{V}^{5+}$ species and isolated $\mathrm{V}^{5+}=\mathrm{O}$ species, respectively $[52,53]$. Therefore, the size of crystals of $\mathrm{V}_{2} \mathrm{O}_{5}$ must be low (they are not observed by $\mathrm{XRD}$ ), and most of $\mathrm{V}$-species are dispersed as $\mathrm{V}^{5+}$ species.

In the case of vanadium oxide supported on $\mathrm{Al}$,Zr-oxide with high $\mathrm{Zr}$-content (CC-series, Figure 2c), $\mathrm{V}_{2} \mathrm{O}_{5}$ is mainly observed for catalysts with V-loading higher than $2 \mathrm{wt} \%$, whereas a broad band at ca. $860 \mathrm{~cm}^{-1}$ is also observed in addition to those related to $\mathrm{V}_{2} \mathrm{O}_{5}$ for catalysts with V-loading of $2 \mathrm{wt} \%$ of V-atoms. However, only the band at $860 \mathrm{~cm}^{-1}$ is observed in the catalysts prepared with a V-content of $1 \mathrm{wt} \%$ of V-atoms. The band at $860 \mathrm{~cm}^{-1}$ was observed previously in supported VOx catalysts [54] and was assigned to $\mathrm{V}-\mathrm{O}-\mathrm{V}$ vibrations in polyvanadate structures for $\mathrm{VOx} / \mathrm{ZrO}_{2}$ catalysts.

The Raman spectra of catalysts supported on $\mathrm{ZrO}_{2}$ (DC-series) (Figure 2d) presents several bands, some of them also observed in the support (V-free). Raman spectrum of pure $\mathrm{ZrO}_{2}$ shows the presence of bands at 175, 190, and $477 \mathrm{~cm}^{-1}$ (related to $\mathrm{m}-\mathrm{ZrO}_{2}$ ) and bands at 263, 330, 472, 552, and $640 \mathrm{~cm}^{-1}$ (related to $\mathrm{t}-\mathrm{ZrO}_{2}$ ) [50]. These results are in good agreement to those previously reported for $\mathrm{V}_{2} \mathrm{O}_{5} / \mathrm{ZrO}_{2}$ catalysts $[50,54]$ in which the Raman spectrum of the supported $4 \% \mathrm{~V}_{2} \mathrm{O}_{5} / \mathrm{ZrO}_{2}$ catalyst (with $8.1 \mathrm{~V}$ at. $/ \mathrm{nm}^{2}$ ) contains bands from the dehydrated surface $\mathrm{VO}_{4}$ species at 1035 and $\sim 935 \mathrm{~cm}^{-1}$ arising from the terminal $\mathrm{V}=\mathrm{O}$ and bridging $\mathrm{V}-\mathrm{O}-\mathrm{Zr}$ bonds, respectively, as well as the presence of band at $860 \mathrm{~cm}^{-1}$ assigned to $\mathrm{V}-\mathrm{O}-\mathrm{V}$ vibrations in polyvanadate structures [52]. The Raman features at $\sim 630$, $\sim 552, \sim 528, \sim 470, \sim 375$, and $\sim 330 \mathrm{~cm}^{-1}$ were related to crystalline monoclinic $\mathrm{ZrO}_{2}$ support [50]. Similar surface $\mathrm{VO}_{4}$ vibrational bands at $\sim 1035$ and $935 / 900 \mathrm{~cm}^{-1}$ are also present in the Raman spectra of the samples supported on $\mathrm{Al}, \mathrm{Zr}$-oxide (with a $\mathrm{Al} /(\mathrm{Al}+\mathrm{Zr}$ ) ratio of 0.75$)$ revealing the presence of bridging $\mathrm{V}-\mathrm{O}-\mathrm{V}$ bonds, whereas the possible presence of broad band at $\sim 580$ and $\sim 800 \mathrm{~cm}^{-1}$ should be related to the polymeric surface vanadia species, and in which V-O-support bond stretches at $900 \mathrm{~cm}^{-1}$ [50]. 

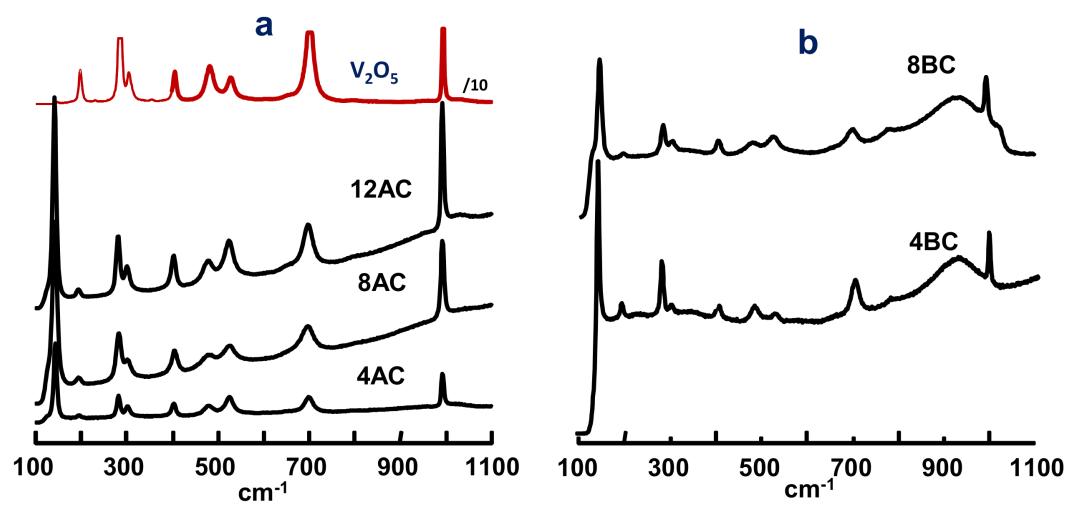

C

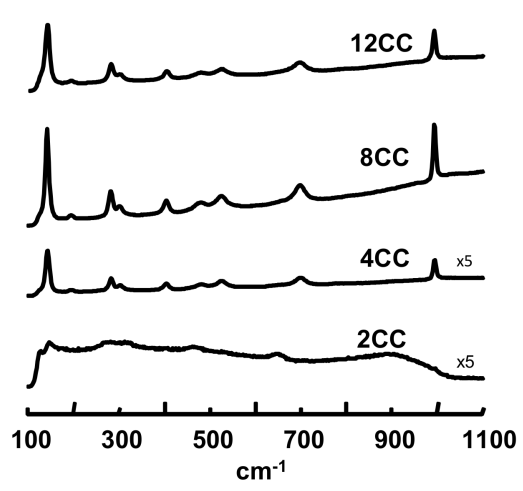

d

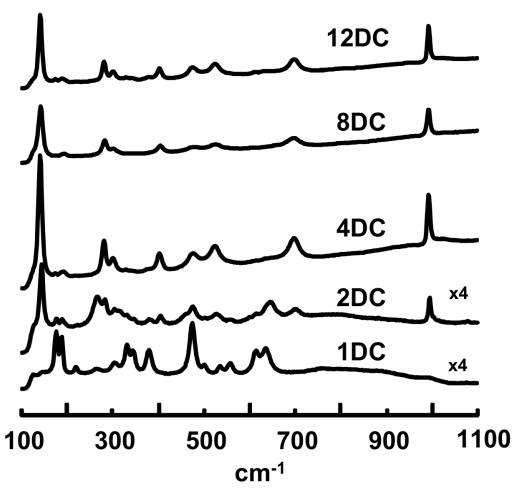

Figure 2. Raman spectra of four sets of catalysts prepared by wet impregnation varying the amount of vanadium over different supports: (a) $\mathrm{Al}_{2} \mathrm{O}_{3}$, (AC-series); (b) $\mathrm{Al} / \mathrm{Zr}$-mixed oxide, $\mathrm{Al} / \mathrm{Zr}=75 / 25$ (BC-series); (c) $\mathrm{Al} / \mathrm{Zr}$-mixed oxide, $\mathrm{Al} / \mathrm{Zr}=25 / 75$ (CC-series); and (d) $\mathrm{ZrO}_{2}$, (DC-series). Catalysts as in Figure 1. For comparison, the Raman spectrum of pure $\mathrm{V}_{2} \mathrm{O}_{5}$ crystalline phase has been also included.

Temperature-programmed reduction (TPR) experiments were carried out on the supported catalysts as it gives us an indication of the reducibility of the catalysts. The $\mathrm{H}_{2}$-TPR profiles are presented in Figure 3 and information about the hydrogen consumption is given in Table 1. For a comparative purpose, Figure $\mathrm{S} 1$ shows the TPR results of some catalysts and pure $\mathrm{V}_{2} \mathrm{O}_{5}$.

In general, the total $\mathrm{H}_{2}$-uptake increases when increasing the V-loading in good agreement with previous results reported by other authors [13-27]. This suggests that all V-atoms are involved in the TPR experiments. However, important differences are observed depending on the support. Thus, a single peak at ca. $450-460{ }^{\circ} \mathrm{C}$ is observed in the case of AC- and BC-series (Figure 3a,b, respectively) with V-loading lower than $8 \mathrm{wt} \%$. However, a second reduction peak at ca. $600{ }^{\circ} \mathrm{C}$ is observed for samples with higher V-loadings (Figure 3a, sample 12AC). A similar effect was observed for $\mathrm{VOx} / \mathrm{Al}_{2} \mathrm{O}_{3}$ catalysts with high V-loadings, which could be related to an incipient $\mathrm{AlVO}_{4}$ phase [55], but also to the presence of small crystals of $\mathrm{V}_{2} \mathrm{O}_{5}$. We must remark that the intensity of the reduction peaks increases with the V-loading, but the temperature of the maximum reduction is similar in both $\mathrm{AC}$ - and BC-series.

On the other hand, in both CC- and DC-series (Figure 3c,d, respectively), it can be observed the presence of two reduction peaks: (i) one peak in the $425-395^{\circ} \mathrm{C}$ range, in which the intensity increases initially with the V-loading up to a V-content of ca. $8 \mathrm{wt} \%$; and (ii) a second reduction peak at ca. $600{ }^{\circ} \mathrm{C}$, in which the intensity increases dramatically for samples with a V-loading higher than $4 \mathrm{wt} \%$. The first reduction peak can be tentatively assigned to isolated or polymeric V-species [15,56], in which the reducibility of $\mathrm{V}$-species in $\mathrm{ZrO}_{2}$-supported catalysts are higher than those in $\mathrm{Al}_{2} \mathrm{O}_{3}$-supported catalysts [56]. The second peak can be related to $\mathrm{V}_{2} \mathrm{O}_{5}$ crystallites on the surface of the support (mainly observed in catalysts with high V-loading), although probably with relatively low crystal size [51], 
and/or attributed to the formation of small $\mathrm{ZrV}_{2} \mathrm{O}_{7}$ crystals [27]. In this way, the reduction of pure $\mathrm{V}_{2} \mathrm{O}_{5}$ appears at temperatures higher than $600{ }^{\circ} \mathrm{C}$ (Figure S1).
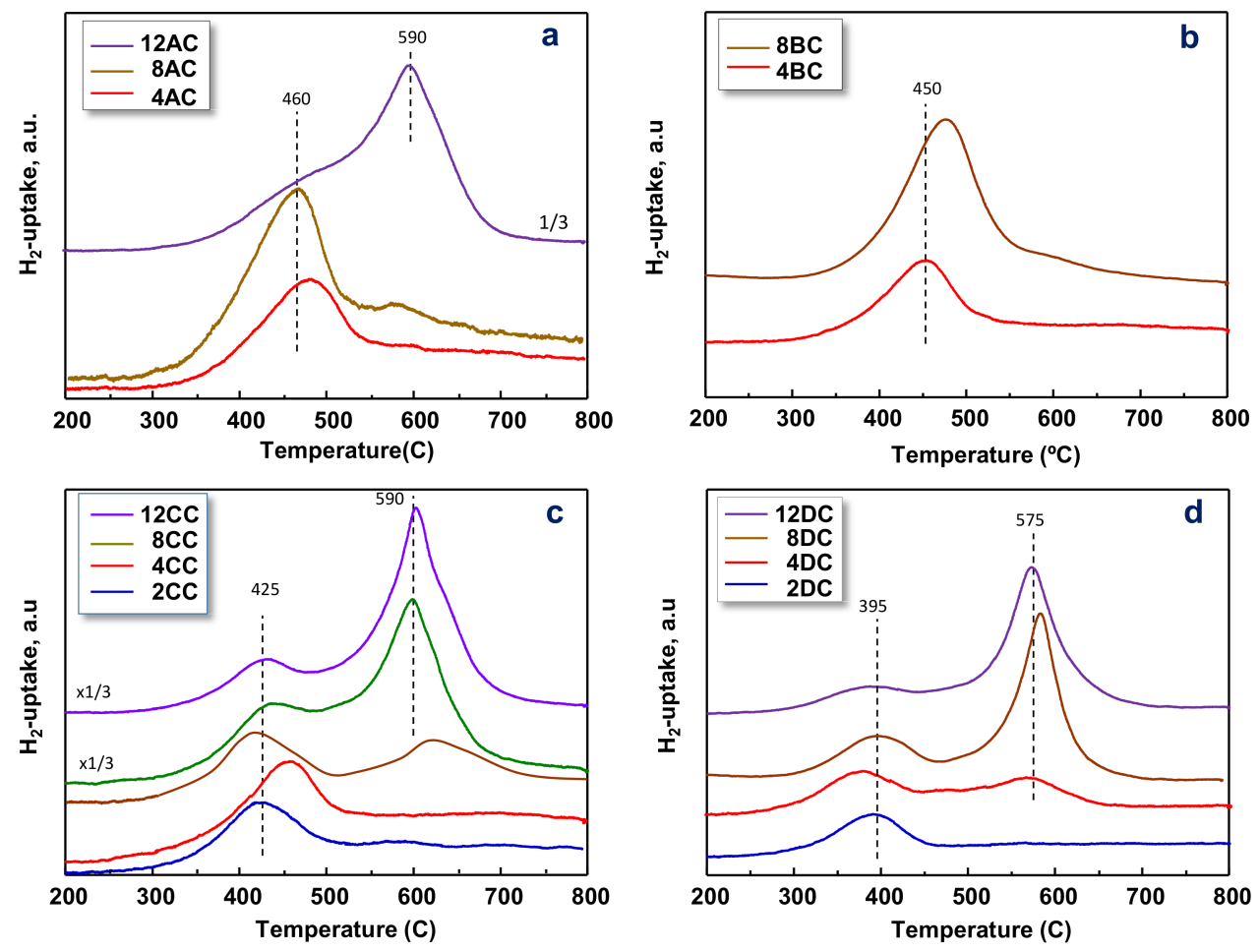

Figure 3. Temperature-programmed reduction (TPR- $\left.\mathrm{H}_{2}\right)$ patterns of supported catalysts prepared by wet impregnation varying the amount of vanadium over different supports: (a) $\mathrm{Al}_{2} \mathrm{O}_{3}$, (AC-series); (b) $\mathrm{Al} / \mathrm{Zr}$-mixed oxide, $\mathrm{Al} / \mathrm{Zr}=75 / 25$ (BC-series); (c) $\mathrm{Al} / \mathrm{Zr}$-mixed oxide, $\mathrm{Al} / \mathrm{Zr}=25 / 75$ (CC-series); and (d) $\mathrm{ZrO}_{2}$, (DC-series). Catalysts are as in Figure 1.

Some representative catalysts have been also studied by XPS. The results are summarized in Table S1 and Figure S2. In all cases, $\mathrm{V}^{5+}$ has been mainly observed, although presenting different environments. The XPS peaks at $517.5 \mathrm{eV}$, the main peak in all cases, is assigned to $\mathrm{V}^{5+}$, whereas the peak at $516.4 \mathrm{eV}$ (as minority in the case of samples 8CC and 8DC) can be related to $\mathrm{V}^{4+}$ species [57,58]. In the case of sample 4BC (Figure S2), it can be also observed a peak at ca. $518.9 \mathrm{eV}$ which is characteristic for highly dispersed $\mathrm{V}^{5+}$ species in supported vanadium oxide catalysts, as proposed previously by Hess et al. [59], which is in agreement with the XRD (Figure 1) and Raman (Figure 2) results.

The acid characteristics of these catalysts have been estimated using temperature-programmed desorption of $\mathrm{NH}_{3}, \mathrm{TPD}-\mathrm{NH}_{3}$ (Figure 4). A maximum at ca. $205^{\circ} \mathrm{C}$ has been observed in all cases with two shoulders at ca. 277 and ca. $350{ }^{\circ} \mathrm{C}$. The most intense band at $205^{\circ} \mathrm{C}$ has been assigned to weak Lewis acid sites of the $\mathrm{VOx} / \mathrm{Al}_{2} \mathrm{O}_{3}$ catalysts, which mainly originate from the exposed alumina sites [53].

Accordingly, for a given support, the amount of acid sites (area inside the curve) decreases with the vanadium loading suggesting that vanadium sites covers the acidic sites of the supports (Figure 4a). For fixed vanadium loading it is observed that the number of acid sites decreases when increasing the amount of $\mathrm{Zr}$ in the support. Thus, the sample supported on $\mathrm{Al}_{2} \mathrm{O}_{3}$ shows the highest amount of acid sites, whereas the sample supported on $\mathrm{ZrO}_{2}$ presented the lower adsorption of ammonia, i.e., the lower amount of acid sites. It is also observed that the intensity of the band at ca. $277^{\circ} \mathrm{C}$ increases in the $\mathrm{Zr}$-rich $\mathrm{Al}, \mathrm{Zr}$-oxide support and that the peak at $350{ }^{\circ} \mathrm{C}$ is hardly appreciated if the support is zirconia. 

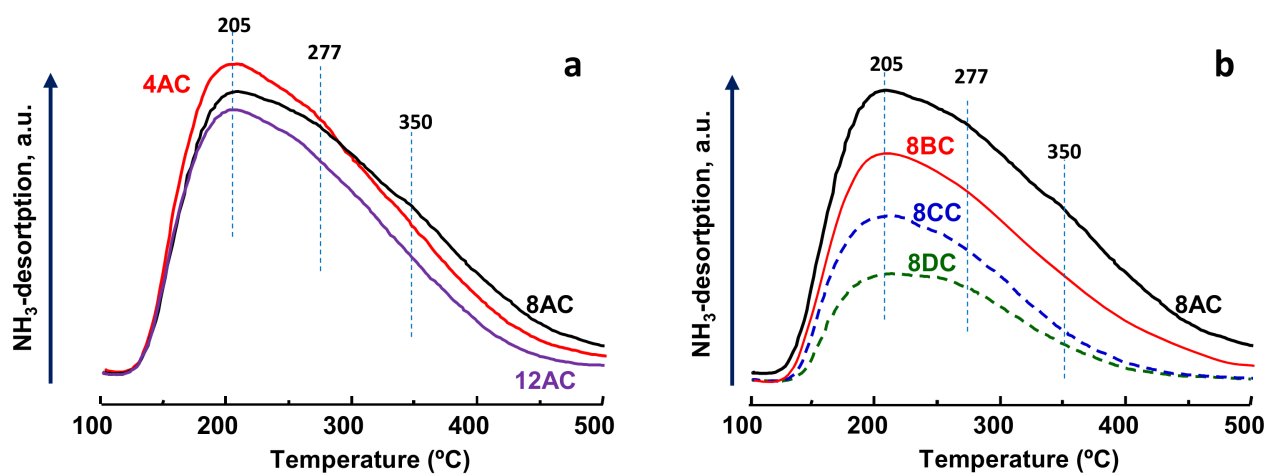

Figure 4. Temperature-programmed desorption of $\mathrm{NH}_{3}\left(\mathrm{TPD}-\mathrm{NH}_{3}\right)$ patterns of catalysts: (a) $\mathrm{Al}_{2} \mathrm{O}_{3}$-Supported catalysts with V-loadings of 4 (4AC), 8 (8AC) and $12 \mathrm{wt} \%$ of $\mathrm{V}$-atoms (12AC); and (b) supported catalysts with a V-loading of $8 \mathrm{wt} \%$ of V-atoms, using different supports: $\mathrm{Al}_{2} \mathrm{O}_{3}$ (sample 8AC); $\mathrm{Al} / \mathrm{Zr}$-mixed oxide, $\mathrm{Al} / \mathrm{Zr}=75 / 25$ (sample 8BC); $\mathrm{Al} / \mathrm{Zr}$-mixed oxide, $\mathrm{Al} / \mathrm{Zr}=25 / 75$ (sample 8CC); and $\mathrm{ZrO}_{2}$ with (sample 8DC).

\subsection{Catalytic Results on $O D H$ of Ethane}

In the $\mathrm{ODH}$ of ethane over supported vanadium oxide catalysts, ethylene, $\mathrm{CO}$ and $\mathrm{CO}_{2}$ have been the main reaction products although the catalytic performance highly varies depending on the catalyst chosen. Figure 5 shows the variation of the ethane conversion with the V-loading for the different supports.

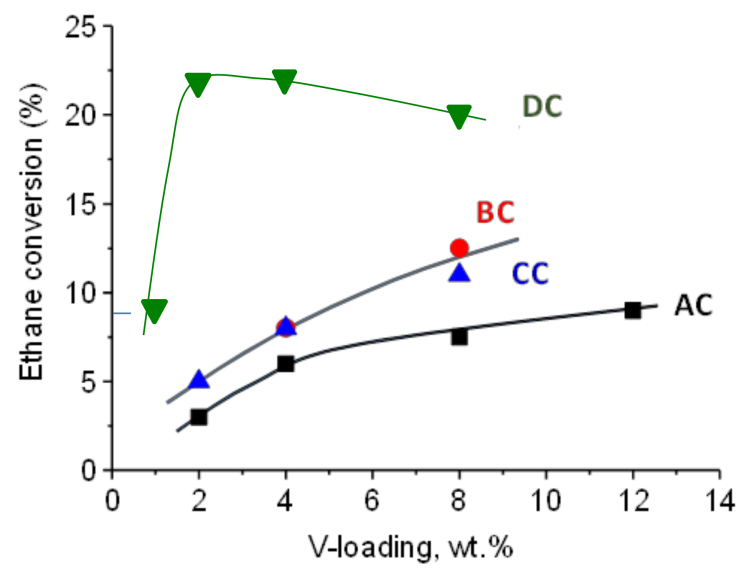

Figure 5. Variation of the ethane conversion with the V-loading for the different series. Notes: $\mathrm{T}=500{ }^{\circ} \mathrm{C}, \mathrm{W} / \mathrm{F}=50 \mathrm{~g}_{\text {cat }} \mathrm{h} \mathrm{mol}_{\mathrm{C} 2 \mathrm{H}_{6}}{ }^{-1}$ and molar ratio $\mathrm{C}_{2} \mathrm{H}_{6} / \mathrm{O}_{2} / \mathrm{He}$ of $4 / 8 / 88$. Symbols:

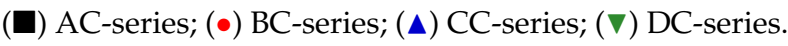

In general, the conversion of ethane increases when increasing the vanadium loading although this effect strongly depends on the nature of the support. Thus, in the case of $\mathrm{Al}_{2} \mathrm{O}_{3}$ and $\mathrm{Al}-\mathrm{Zr}$-O-supported catalysts the activity increases with the $\mathrm{V}$-content, whereas if the support is pure zirconia, the catalytic activity increases up to $4 \mathrm{wt} \%$ and then slightly falls. This change in catalytic activity can be related in the last case to the formation of $\mathrm{V}-\mathrm{Zr}$-O compounds and the presence of $\mathrm{V}$-species in the bulk of the catalyst for V-loading higher than $4 \mathrm{wt} \%$. This effect can be also related not only to the higher reactivity of $\mathrm{ZrO}_{2}$ with respect to $\mathrm{Al}_{2} \mathrm{O}_{3}$, but also to the lower surface area of $\mathrm{ZrO}_{2}$, which favors a lower number of dispersed $\mathrm{V}$ atoms on the surface of the support. Thus, the catalytic activity for ethane ODH decreases in the following trend [59]: $\mathrm{VOx} / \mathrm{ZrO}_{2}>\mathrm{VOx} /\left(\mathrm{Al}, \mathrm{Zr}\right.$-oxides) $>\mathrm{VOx} / \mathrm{Al}_{2} \mathrm{O}_{3}$.

It has been previously suggested that the reactivity of the supported vanadia catalysts for alkane ODH is also a strong function of the specific oxide supports [53,54]. This is in good agreement 
with the catalytic results presented here in which $\mathrm{ZrO}_{2}$-supported catalysts are more active than $\mathrm{Al}_{2} \mathrm{O}_{3}$-supported catalysts (see Figure 5).

Figure 6 shows the variation of the selectivity to the main reaction products (ethane, $\mathrm{CO}$, and $\mathrm{CO}_{2}$ ) with the ethane conversion for catalysts of AC-, BC-, CC-, and DC-series. In general, no influence of V-loading on selectivity to ethylene is observed for each specific series. In addition, the selectivity to ethylene decreases when increasing the ethane conversion, suggesting that ethylene is partially transformed (to carbon oxides, especially carbon monoxide) when working at higher ethane conversion levels (Figure 6). However, according to the results of Figure 6, it can be also concluded that the selectivity to ethylene strongly depend on the nature of metal oxide support. Thus, the catalysts supported on alumina (AC-series, with 4,8 , and $12 \mathrm{wt} \%$ of $\mathrm{V}$ atoms) are the most selective at low ethane conversion (selectivity to ethylene of ca. $70 \%$ is observed) (Figure 6a), whereas those supported on zirconia (DC-series, with 2, 4, 8, and $12 \mathrm{wt} \%$ of $\mathrm{V}$ atoms) present the lowest selectivity to ethylene (ca. $40 \%$ ) (Figure $6 \mathrm{~d}$ ). In the case of vanadium catalysts supported on $\mathrm{Al}$ and $\mathrm{Zr}$ oxides (BC-series with 4 or $8 \mathrm{wt} \%$ of V-atoms; and CC-series with 2, 4, 8, $10 \mathrm{wt} \%$ of $\mathrm{V}$-atoms) (Figure $6 \mathrm{~b}, \mathrm{c}$, respectively), the selectivity to ethylene shows an intermediate behavior to those achieved over alumina-and zirconia-supported vanadium oxide catalysts. In a similar way, the selectivity to ethylene also changes at higher ethane conversion, depending on the type of support. In this ways, at ethane conversion of $30 \%$, catalysts of $\mathrm{AC}$ - and BC-series present the highest selectivity to ethylene (ca. 50\%) and the lowest selectivity to CO (ca. 45\%), whereas those of CC- and DC-series present the lowest selectivity to ethylene (ca. $27 \%$ ) and the highest selectivity to $\mathrm{CO}$ (ca. $55 \%$ ). Accordingly, at isoconversion conditions, the selectivity to ethylene decreases as follow: $\mathrm{VOx} / \mathrm{Al}_{2} \mathrm{O}_{3}>$ $\mathrm{VOx} /\left(\mathrm{Al}, \mathrm{Zr}\right.$-oxides) $>\mathrm{VOx} / \mathrm{ZrO}_{2}$ (see also Figure S3, Supporting Information). This is an opposite trend to that observed for the catalytic activity in ethane ODH of these catalysts (Figure 5).
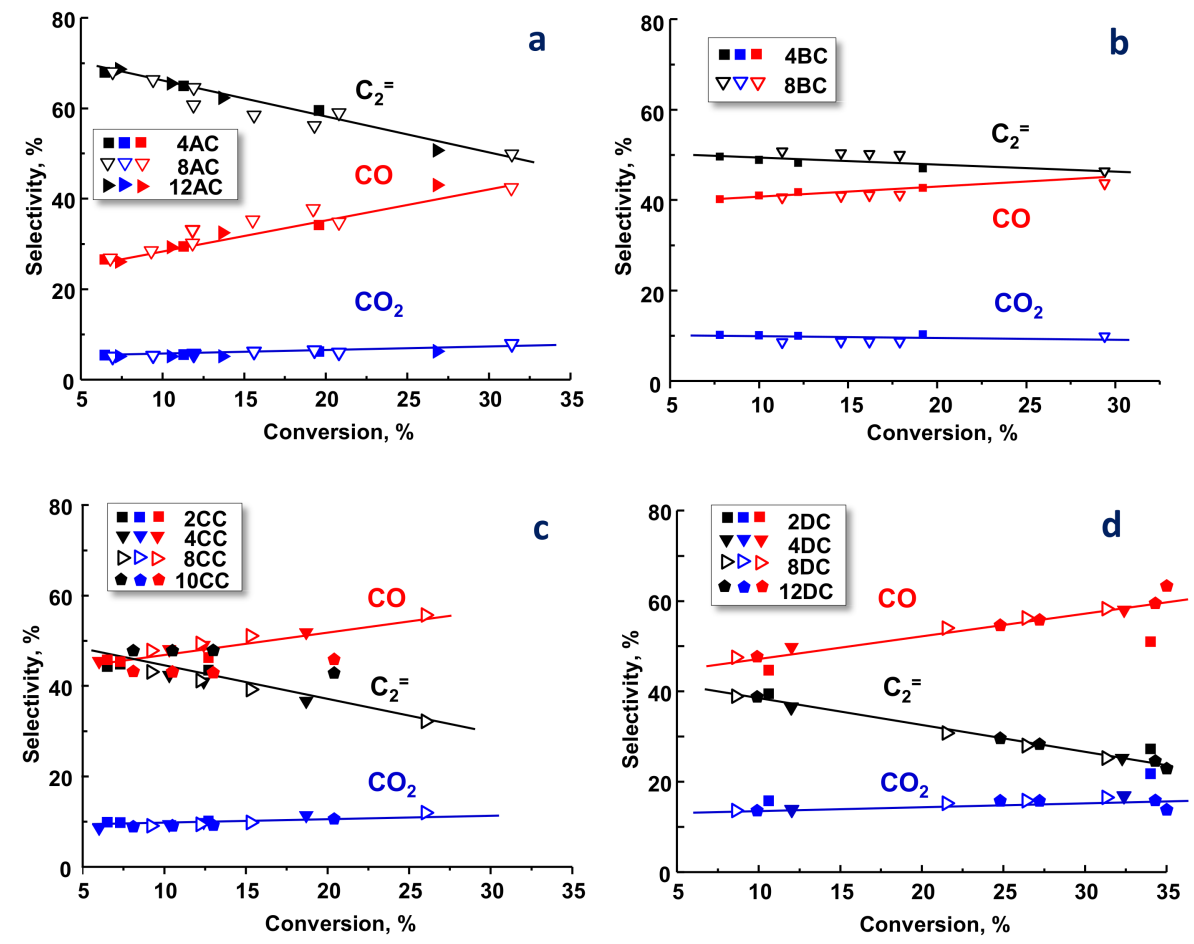

Figure 6. Variation of the selectivity to ethylene, $\mathrm{CO}$ and $\mathrm{CO}_{2}$ with ethane conversion during the ODH of ethane on supported vanadium oxide catalysts: (a) AC-series; (b) BC-series; (c) CC-series; and (d) DC-series. Reaction conditions: $\mathrm{T}=500-530{ }^{\circ} \mathrm{C}$ and molar ratio $\mathrm{C}_{2} \mathrm{H}_{6} / \mathrm{O}_{2} / \mathrm{He}$ of $4 / 8 / 88$. Several contact times $(\mathrm{W} / \mathrm{F})$ were used in order to get different ethane conversions. See also Tables S2-S5. 
We want to note that alumina-supported vanadium oxide catalysts prepared by this preparation method presents selectivity to ethylene similar to those of vanadium prepared on commercial $\gamma-\mathrm{Al}_{2} \mathrm{O}_{3}$ (see Figure S4, Supporting Information), suggesting that in both cases we likely have similar dispersion of vanadium on the metal oxide support. On the other hand, the presence of V-free sites of support should have a relatively low influence on selectivity to ethylene. Thus, the surface area of catalysts seems to have little influence on the final selectivity to ethylene.

According to these catalytic results, a reaction network can be proposed (Figure 7), in which $\mathrm{CO}$ is formed from both ethane and ethylene deep oxidation, and $\mathrm{CO}_{2}$ is mainly formed by the deep oxidation of ethane.

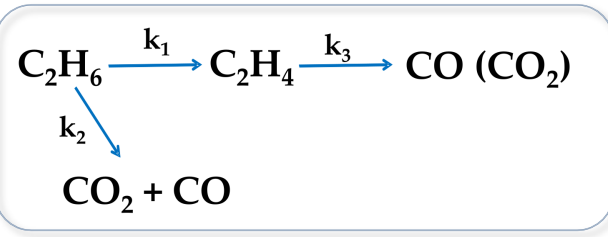

Figure 7. Reaction network for the oxidative dehydrogenation of ethane over supported vanadium oxide catalysts.

\subsection{Selective Aerobic Transformation of Methanol}

Selective transformation of methanol tests have been focused in the catalysts with $8 \mathrm{wt} \% \mathrm{~V}$. Formaldehyde $\left(\mathrm{CH}_{2} \mathrm{O}\right)$, dimethylether (DME) and carbon oxides $\left(\mathrm{CO}\right.$ and $\left.\mathrm{CO}_{2}\right)$ are the main reaction products. In addition, dimethoxymethane (DMM), which is formed from the decomposition of formaldehyde and methyl formate were also observed as minorities.

Figure 8 shows the variation of the conversion of methanol with reaction temperature of all studied catalysts. The most active catalyst is that with zirconia as a support whereas the least active one corresponds to the catalyst supported on alumina. V-catalysts on mixed $\mathrm{Al}_{2} \mathrm{O}_{3} / \mathrm{ZrO}_{2}$ supports present an intermediate catalytic activity between the pure supports. This trend is similar to that observed in the ethane ODH although the variation of activity is lower in methanol activation.

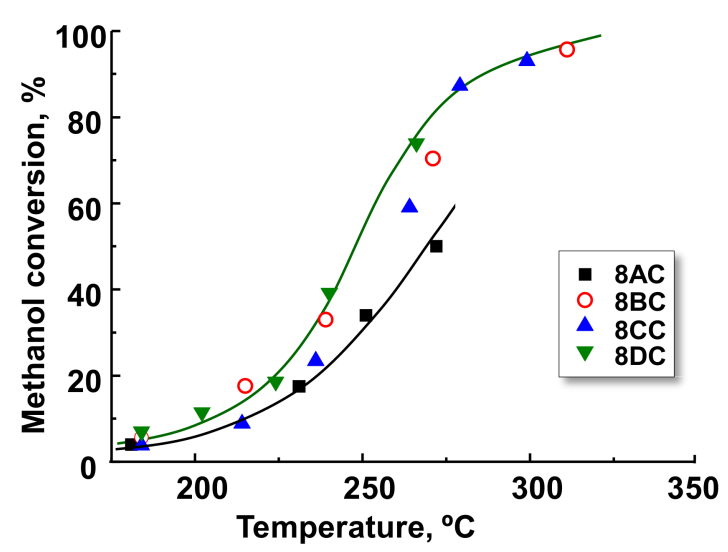

Figure 8. Variation of the methanol conversion with the reaction temperature during the aerobic methanol conversion over supported vanadium oxide catalysts. Notes: reaction conditions in text.

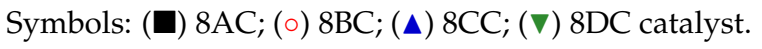

However, as it will be discussed later, this behavior is explained by considering that both redox and acid sites are involved in the aerobic transformation of methanol. Accordingly, and considering that the reactivity of acid sites is different to the reactivity of redox sites, the total conversion of methanol should be explained by these two parameters. The different nature and relative reactivity of 
the active sites between the ODH (where redox sites are the predominant) of ethane and methanol oxidation can account for this different performance.

Figure 9 presents the variation of the selectivity to formaldehyde (or to formaldehyde + DMM, at low reaction temperature) and the selectivity to DME with the methanol conversion. It can be observed that formaldehyde and DME are formed in all cases, although depending on the characteristics of catalysts the ratio of formaldehyde and DME ratio could change. This change is indicative of the ratio between acid and redox sites.
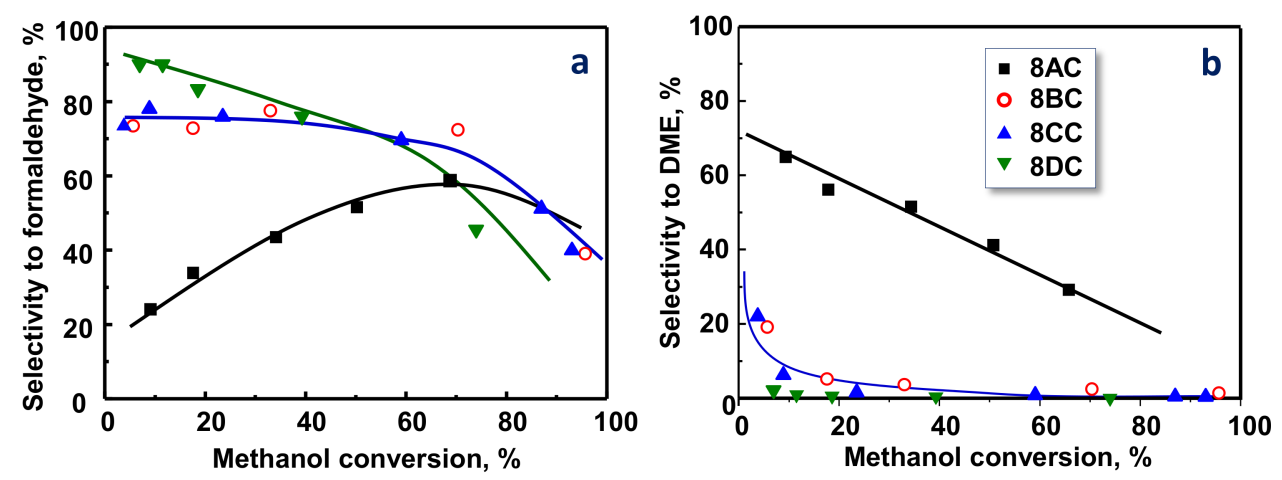

Figure 9. Variation of the selectivity to formaldehyde (or formaldehyde + dimetoxymethane, i.e., FA + DMM) (a) and the selectivity to dimethyl ether (DME) (b) with the methanol conversion achieved during the methanol transformation. Notes: Reaction conditions in text. Symbols: (ם) 8AC; (o) 8BC;

(ム) $8 \mathrm{CC} ;(\boldsymbol{\nabla})$ 8DC catalyst.

In the same way, we compared the catalytic performance of alumina-supported vanadium oxide catalysts using commercial Alumina, i.e., $\mathrm{V}(4 \mathrm{wt} \%) / \mathrm{Al}$ and $\mathrm{V}(8 \mathrm{wt} \%) / \mathrm{Al}$ samples, and home-made alumina containing catalysts (i.e., $4 \mathrm{AC}$ and $8 \mathrm{AC}$ samples). The variation of the selectivity to formaldehyde (or to formaldehyde + dimetoxymethane at low reaction temperature) and the selectivity to dimethyl ether (DME) with the methanol conversion are shown in Figure S5 (Supporting Information). According to these results, the presence of more vanadium on the catalyst surface (decreasing the alumina concentration on the catalyst surface) could favor a higher formaldehyde formation as the redox reaction is favored and also a lower DME formation as the concentration of acid sites decreases.

Thus, according to these results, the sample with alumina support, 8AC, presents a high concentration of acid sites (the highest yield to DME and the lowest to formaldehyde). In an opposite trend, the catalysts with zirconia-alumina supports present a very low concentration of acid sites (high yield to formaldehyde and poor to DME). Finally, no DME was observed in the series with pure zirconia as a support, suggesting the absence of acid sites.

\subsection{General Remarks}

According to the results observed in this work, alumina seems to be the preferred support for vanadium to obtain efficient catalysts for the ODH of ethane. However, this is true only at low and moderate ethane conversions, as vanadium supported on mixed $\mathrm{Al}_{2} \mathrm{O}_{3}-\mathrm{ZrO}_{2}$ with low amount of zirconia (i.e., $75 \mathrm{Al}-25 \mathrm{Zr}$ support) mitigates the decomposition of the olefin. Consequently, for a selected vanadium loading, the selectivity to ethylene achieved at conversions over $30 \%$ is the highest in the catalysts using the 75Al-25Zr support and higher than that achieved on the catalysts supported on pure alumina. These results are not straightforward to explain but are likely related to the dispersion of vanadium species and especially to the acid/redox characteristics of the supports/catalysts. Thus, the incorporation of low amounts of zirconia expands the support structure, thus increasing the surface area and then improving the dispersion of vanadium species (see characterization data). Moreover, in view of methanol transformation results, the proportion of acid/redox sites decreases when zirconia 
is incorporated. Thus, in addition to redox sites, acid sites are also required as they favor a higher desorption of ethylene $[5-7,16]$. In fact, the presence of redox sites is required since they are responsible for the ethane to ethylene reaction. However, they are also directly involved in the combustion of ethane. Accordingly, the presence of acid sites can decrease the concentration of ethylene adsorbed on the catalyst surface favoring a lower degradation of ethylene.

As it has been reported in the past, acidic supports are preferred over basic ones [5-26] as supports of vanadium oxide for the ODH of ethane; however, acidic sites themselves could be active in the olefin decomposition and then this can be related to the fact that the replacement of a part of the alumina by zirconia decreases the drop of the ethylene selectivity when the conversion of ethane is increased. However, the low selectivity to ethylene and the high selectivity to carbon oxides in catalysts with high $\mathrm{Zr}$-loading has been reported to be related to the presence of dispersed $\mathrm{V}$-species (at low surface densities) and bulk $\mathrm{ZrV}_{2} \mathrm{O}_{7}$. It appears to be associated with exposed unselective $\mathrm{V}-\mathrm{O}-\mathrm{Zr}$ and $\mathrm{Zr}-\mathrm{O}-\mathrm{Zr}$ sites [60] which are especially active in the alkane combustion. In catalysts with high Zr-loading (CC- and DC-series) the selectivity to ethylene is very low. In addition, it has also been proposed that the rates for alkane ODH increase initially as the size of polyvanadate domains increases (i.e., increasing VOx surface density). Thus, the rate of ODH decreases with the formation of $\mathrm{V}_{2} \mathrm{O}_{5}$ clusters (usually at high surface densities in which the fraction of VOx species exposed at cluster surfaces decreases). Our catalytic results indicate that the polymerization degree of the surface vanadia species does not significantly affect the reactivity of the catalysts for ethane oxidation but the increase in the crystallite size of $\mathrm{V}_{2} \mathrm{O}_{5}$ crystallites leads to a decrease in the activity per V-site. In the DC-series the ethane conversion (Figure 5) reaches a maximum at $2 \mathrm{wt} \% \mathrm{~V}$ and for higher V-loadings, in which the vanadium pentoxide crystallite size increases, the activity per gram of catalyst slightly drops.

The formation of complex oxides with vanadium, zirconium and aluminum cannot be ruled out (V-Al-Zr-O species), although we do not have conclusive evidences. Vanadium in this ternary oxide can have different characteristics that those of vanadium supported on pure alumina or pure zirconia, then affecting the catalytic performance.

Another parameter that could have some influence on the catalytic performance in the ODH of ethane is the oxidation state of vanadium in the surface. Thus, in the present work, the least selective catalysts studied are those with some $\mathrm{V}^{4+}$ (samples 8CC and 8DC) whereas in the most selective catalysts, samples $4 \mathrm{AC}$ and $4 \mathrm{BC}$, no appreciable $\mathrm{V}^{4+}$ has been observed. However, we cannot conclusively state that the presence of $\mathrm{V}^{4+}$ in the catalysts is deleterious for the ODH of ethane since in all cases the amount of $\mathrm{V}^{4+}$ has been low $(<6 \%)$. The presence of dispersed $\mathrm{V}^{5+}$ species in $4 \mathrm{BC}$ could be related to the lower ethylene decomposition (lower fall in the selectivity to ethylene when the ethane conversion increases) compared to other catalysts.

According to kinetic aspects of the ODH reactions $[5-7,17,23,26,27,61,62]$ and the results obtained in the present work a simplified reaction network can be tentatively proposed. It must be mentioned that more catalytic data would be needed for a comprehensive kinetic analysis. A reaction network with parallel and consecutive reactions has been proposed, Figure 7 , in which $\mathrm{k}_{1}, \mathrm{k}_{2}$, and $\mathrm{k}_{3}$ are kinetic constants. In this reaction network, the initial selectivity to olefin (at low conversion of alkane) will be related to the $k_{1} / k_{2}$ ratio while at high alkane conversion levels, the selectivity to olefins will be associated to the $k_{1} /\left(k_{2}+k_{3}\right)$ ratio. However, in our case, it is possible to propose a more adequate reaction network in which the main formation of both $\mathrm{CO}$ and $\mathrm{CO}_{2}$ can be directly assigned to different reaction step. In fact, the selectivity to ethylene decreases and the selectivity to $\mathrm{CO}$ increases when increasing the ethane conversion. Apparently, ethylene is mainly transformed into $\mathrm{CO}$ when increasing the ethane conversion. However, the selectivity to $\mathrm{CO}_{2}$ remains practically constant in the ethane conversion region studied (see Figure $6 \mathrm{c}$ for samples supported over $\mathrm{Al}_{2} \mathrm{O}_{3}$, i.e., $\mathrm{AC}$-series). Thus, $\mathrm{CO}_{2}$ is mainly formed by parallel reaction from ethane. However, the formation of $\mathrm{CO}$ occurs by both the deep oxidation of ethane and the deep oxidation of ethylene (the ratio of both reactions depending on the nature of catalysts). According to our results the incorporation of zirconia to alumina decreases the 
$\mathrm{k}_{1} / \mathrm{k}_{2}$ ratio but also the $\mathrm{k}_{3} /\left(\mathrm{k}_{1}+\mathrm{k}_{2}\right)$ ratio. Thus, at low zirconia loadings, a compromise between both factors takes place, thus obtaining the highest selectivity to ethylene at high ethane conversions.

\section{Materials and Methods}

\subsection{Preparation of Metal Oxide Support}

Different metal support with $\mathrm{Al} /(\mathrm{Al}+\mathrm{Zr})$ ratios of $1,0.75,0.25$, and 0 have been synthesized. The synthesis of supports was carried by calcination at $500{ }^{\circ} \mathrm{C}$, during $5 \mathrm{~h}$ under a stream of oxygen, from the corresponding hydroxides precursors. The aluminum and/or zirconium hydroxides, i.e., $\mathrm{Al}(\mathrm{OH})_{3}$, $\mathrm{Zr}(\mathrm{OH})_{4}$ or $\mathrm{Zr}(\mathrm{OH})_{4}-\mathrm{Al}(\mathrm{OH})_{3}$, were prepared by precipitation at $\mathrm{pH}=10$, by adding a $30 \% \mathrm{NH}_{4} \mathrm{OH}$ solution to aqueous solutions of $\mathrm{AlCl}_{3} \cdot 6 \mathrm{H}_{2} \mathrm{O}$ and / or $\mathrm{ZrOCl}_{2} \cdot 8 \mathrm{H}_{2} \mathrm{O}$ (with adequate $\mathrm{Al} / \mathrm{Zr}$ molar ratio). The white gels were then washed with distilled water to remove the $\mathrm{Cl}$-ions in excess, followed by filtration and drying at $110^{\circ} \mathrm{C}$. The final metal oxide supports correspond to: (i) $\mathrm{Al}_{2} \mathrm{O}_{3}$, with a surface area of $168 \mathrm{~m}^{2} \mathrm{~g}^{-1}$ (named as $\mathrm{AC}$ ); (ii) $\mathrm{ZrO}_{2}-\mathrm{Al}_{2} \mathrm{O}_{3}$ mixed metal oxides, with a $\mathrm{Al} /(\mathrm{Al}+\mathrm{Zr}$ ) at ratio of 0.75 , with a surface area of $180 \mathrm{~m}^{2} \mathrm{~g}^{-1}$ (named as BC); (iii) $\mathrm{ZrO}_{2}-\mathrm{Al}_{2} \mathrm{O}_{3}$ mixed metal oxides, with a $\mathrm{Zr} /\left(\mathrm{Al}+\mathrm{Zr}\right.$ ) at ratio of 0.75 , with a surface area of $99 \mathrm{~m}^{2} \mathrm{~g}^{-1}$ (named as CC); and (iv) $\mathrm{ZrO}_{2}$, with a surface area of $38 \mathrm{~m}^{2} \mathrm{~g}^{-1}$ (named as DC).

\subsection{Preparation of Catalyst}

Supported vanadium oxide catalysts were prepared by wet impregnation method, using aqueous solution of ammonium metavanadate, and rotaevaporated in vacuum at $60^{\circ} \mathrm{C}$. The paste obtained was dried in a furnace at $100{ }^{\circ} \mathrm{C}$ overnight and calcined in static air for $6 \mathrm{~h}$ at $500{ }^{\circ} \mathrm{C}$. The catalysts will be named as $\mathrm{nAC}, \mathrm{nBC}, \mathrm{nCC}, \mathrm{nDC}$ (in which $\mathrm{n}$ is the V-loading, in $\mathrm{wt} \%$ of $\mathrm{V}$-atoms), and $\mathrm{AC}, \mathrm{BC}, \mathrm{CC}$, and $\mathrm{CD}$ correspond to the home made supports mentioned above. Some physicochemical properties of the supported vanadium oxide catalysts are shown in Table 1.

\subsection{Characterization Techniques}

Catalyst surface areas were determined by multi-point $\mathrm{N}_{2}$ adsorption at $-196{ }^{\circ} \mathrm{C}$. The data were treated in accordance with the BET method.

Powder X-ray diffraction (XRD) was used to identify the crystalline phases present in the catalysts. An Enraf Nonius FR590 sealed tube diffractometer (Bruker, Delft, The Netherlands), with a monochromatic $\mathrm{CuK} \alpha 1$ source operating at $40 \mathrm{kV}$ and $30 \mathrm{~mA}$ was used.

Raman spectra were obtained with an "in via" Renishaw spectrometer, equipped with an Olympus microscope Renishaw, Gloucestershire, UK), using an exciting wavelength of $514 \mathrm{~nm}$ (from a Renishaw HPNIR laser with a power of approximately $15 \mathrm{~mW}$ on the sample).

Temperature-programmed reduction (TPR) was carried out in a Micromeritics Autochem 2910 (Micromeritics, Norcross, GA, USA) equipped with a TCD detector, in which the reducing gas was $10 \%$ $\mathrm{H}_{2}$ in $\mathrm{Ar}$ (total flow rate of $50 \mathrm{~mL} \mathrm{~min}^{-1}$ ). The temperature range explored was from room temperature to $800{ }^{\circ} \mathrm{C}$. The heating rate was maintained at $10^{\circ} \mathrm{C} \mathrm{min}^{-1}$.

Experiments of temperature-programmed desorption of ammonia (TPD- $\mathrm{NH}_{3}$ ) were carried out on a TPD/2900 apparatus (Micromeritics, Norcross, GA, USA). Three-hundred milligrams of sample was pre-treated in a He stream at $450{ }^{\circ} \mathrm{C}$ for $1 \mathrm{~h}$. Ammonia was then chemisorbed by pulses at $100^{\circ} \mathrm{C}$ until equilibrium was reached. Finally, the sample was fluxed with a He stream for $15 \mathrm{~min}$, prior to increasing the temperature up to $500{ }^{\circ} \mathrm{C}$ in a helium stream of $100 \mathrm{~mL} \mathrm{~min}^{-1}$ and using a heating rate of $10^{\circ} \mathrm{C} \mathrm{min}^{-1}$. Desorption of $\mathrm{NH}_{3}$ was monitored with a thermal conductivity detector (TCD).

The chemical characterization of the near surface of the catalysts was performed by XPS. A Physical Electronics spectrometer (PHI 5700) (PHI, Chanhassen, MN, USA) with X-ray Mg K $\alpha$ radiation $(300 \mathrm{~W}, 15 \mathrm{kV}, 1253.6 \mathrm{eV})$ as the excitation source was used for high-resolution record. Measurements were conducted by a concentric hemispherical analyzer which operates in the constant pass energy mode at $29.35 \mathrm{eV}$, using a $720 \mu \mathrm{m}$ diameter analysis area. 


\subsection{Catalytic Studies}

The catalytic tests for both ethane ODH and the aerobic transformation of methanol were carried out at atmospheric pressure in a fixed-bed quartz tubular flow reactor [33]. The reaction temperature has been controlled by a thermocouple placed inside the catalytic reactor at the level of the catalyst bed.

In the case of ethane $\mathrm{ODH}$, the catalyst weight was varied and the total flow of ethane/oxygen/helium with a molar ratio of 4/8/88 (maintaining a total flow of $100 \mathrm{~mL} \mathrm{~min}{ }^{-1}$ ) was used. The protocol employed for the catalytic study in the oxidative dehydrogenation of ethane using these catalysts was as follows. Firstly we conducted a series of experiments at $500{ }^{\circ} \mathrm{C}$ and a contact time of $50 \mathrm{~g}_{\text {cat }} \mathrm{h} \mathrm{molC}_{2}{ }^{-1}$ (this corresponds to $0.25 \mathrm{~g}$ of catalyst and a total flow of $50 \mathrm{~mL} \mathrm{~min}-1$ ) with all catalysts. As the reactivity of the catalysts was different, several contact times have been employed in order to reach conversions until ca. 30\%. With the least active catalysts, i.e., 2CC, contact times higher than 50 were used (until $250 \mathrm{~g}_{\text {cat }} \mathrm{h} \mathrm{molC}{ }_{2}{ }^{-1}$ which corresponds to $1.25 \mathrm{~g}$ of catalyst and a flow of $50 \mathrm{~mL} \mathrm{~min}^{-1}$ ). In the case of the most active catalysts, i.e., DC-series, contact times lower than $50 \mathrm{~g}_{\text {cat }} \mathrm{h} \mathrm{molC}_{2}{ }^{-1}$ were used (until $10 \mathrm{~g}_{\text {cat }} \mathrm{h} \mathrm{mol} \mathrm{C2}^{-1}$ which corresponds to $50 \mathrm{mg}$ of catalyst and a flow of $50 \mathrm{~mL} \mathrm{~min}^{-1}$ ). As the amount of sample employed largely varies depending on the experiment, the catalysts have been diluted with silicon carbide in order to have a catalytic bed with a constant volume.

Analysis of the reaction products was carried out on-line using gas chromatography [31,32]. Two GC columns were employed in the analysis of the reactants and reaction products: Porapak $Q$ and Molecular Sieve 5A. Porapak Q (3 m long) has been used to identify hydrocarbons, mainly ethane and ethylene, water, and carbon dioxide. As this column cannot split oxygen properly and carbon monoxide a second column (molecular sieve $5 \mathrm{~A}, 3 \mathrm{~m}$ long) was used to quantify $\mathrm{O}_{2}$ and $\mathrm{CO}$. The temperature of the columns in the analysis was fixed in $80^{\circ} \mathrm{C}$ and the total flow of the helium carrier gas maintained in $30 \mathrm{~mL} \mathrm{~min}^{-1}$.

The aerobic transformation of methanol was carried out in the $250-400{ }^{\circ} \mathrm{C}$ temperature range. 50 to $250 \mathrm{mg}$ of catalyst (diluted with $0.5 \mathrm{~g} \mathrm{CSi}$ ) and a feed consisted of a methanol/oxygen/nitrogen mixture with a molar ratio of $6 / 13 / 81$ (total flow of $100 \mathrm{~mL} \mathrm{~min}^{-1}$ ) were used. The analysis of reactants and products was carried out by means of gas-chromatography, using two different chromatographic columns [47]: (i) RTU-bond ( $30 \mathrm{~m}, 0.53$ i.d.); and (ii) molecular sieve $5 \mathrm{~A}$ ( $3 \mathrm{~m}$ length).

Blank runs in the absence of catalysts have been carried out until $550{ }^{\circ} \mathrm{C}\left(50^{\circ} \mathrm{C}\right.$ higher than the highest temperature used in this study) maintaining the ethane/oxygen/helium molar ratio of 4/8/88. Ethane conversions lower than $0.2 \%$ were observed in all of the experiments conducted.

\section{Conclusions}

Alumina-supported vanadia catalysts are more selective to ethylene in the ODH of ethane than the corresponding catalysts supported on $\mathrm{Zr}$-containing metal oxides. The selectivity to ethylene decreases and the selectivity to CO increases when increasing the Zr-content in the support. In a parallel way, it has been observed that the acid characteristics of supports also decreases when increasing Zr-content as concluded from both TPD- $\mathrm{NH}_{3}$ and the aerobic transformation of methanol. Accordingly, the presence of acid sites could favor a rapid desorption of ethylene favoring a higher selectivity to olefin (and a lower ethylene degradation to $\mathrm{CO}$ ). Overall, alumina has demonstrated to present the highest selectivity to ethylene. However, the partial replacement of alumina by zirconia $\left(75 \% \mathrm{Al}_{2} \mathrm{O}_{3} / 25 \% \mathrm{ZrO}_{2}\right)$, has led to an enhanced selectivity to ethylene at high ethane conversions in the ODH of ethane. This increase of the selectivity to ethylene is due to a lower ethylene decomposition which can be related to a better V-dispersion and a higher proportion of redox sites, as corroborated in the methanol oxidation tests. Thus, a compromise between acid and redox sites seems to be necessary to obtain high selectivity to ethylene at high ethane conversion. However, if supports with high Zr-loadings are used (i.e., high $\mathrm{Zr} / \mathrm{Al}$ ratios or pure $\mathrm{ZrO}_{2}$ ) a drastic decrease in the ethylene formation, but also in the ethylene degradation (with CO formation) is observed due to their low acid character, the formation of 
unselective $\mathrm{V}-\mathrm{O}-\mathrm{Zr}$ sites and the low $\mathrm{V}$-dispersion capacity as a consequence of the low surface area of the supports.

Supplementary Materials: The following are available online at http:/ /www.mdpi.com/2073-4344/8/4/126/s1, Figure $\mathrm{S} 1$. TPR $-\mathrm{H}_{2}$ results of supported catalysts. For comparison it has also been included in the results for pure $\mathrm{V}_{2} \mathrm{O}_{5}$. Characteristics of catalysts are shown in Table 1. Table S1. XPS results of supported catalysts. Figure S2. $\mathrm{V} 2 \mathrm{p}_{3 / 2}$ photoelectron spectra of catalysts with a V-loading of 4 or $8 \mathrm{wt} \%$ of V-atoms. Characteristics of catalysts in Table 1, Table S2. Catalytic results during the ethane ODH over catalysts of AC-series. Table S3. Catalytic results during the ethane ODH over catalysts of BC-series. Table S4. Catalytic results during the ethane ODH over catalysts of CC-series. Table S5. Catalytic results during the ethane ODH over catalysts of DC-series. Figure S3. Variation of the selectivity to ethylene with V-loading during the ODH of ethane over supported vanadium oxide catalysts (AC, BC, CC and DC series) at an ethane conversion of: (a) $5 \%$; and (b) $35 \%$. Reaction conditions: $\mathrm{T}=500{ }^{\circ} \mathrm{C}$; ethane/oxygen/helium with a molar ratio of $4 / 8 / 88$. Figure S4. Variation of the selectivity ethylene, $\mathrm{CO}$ and $\mathrm{CO}_{2}$ with ethane conversion during the $\mathrm{ODH}$ of ethane over $\mathrm{Al}_{2} \mathrm{O}_{3}$-supported vanadium oxide catalysts (V/Al series, prepared over commercial $\mathrm{Al}_{2} \mathrm{O}_{3}$ support). Reaction conditions: $\mathrm{T}=500^{\circ} \mathrm{C}$; ethane/oxygen/helium with a molar ratio of $4 / 8 / 88$. Figure S5. Variation of the selectivity to formaldehyde (or formaldehyde + DMM) left) and to DME (right) with methanol conversion during the aerobic transformation of methanol over $\mathrm{Al}_{2} \mathrm{O}_{3}$-supported vanadium oxide catalysts ( $\mathrm{V} / \mathrm{Al}$ series: $\mathrm{V}(4 \mathrm{wt} \%) / \mathrm{Al}$ and $\left.\mathrm{V}(8 \mathrm{wt} \%) / \mathrm{Al}\right)$, prepared over commercial $\mathrm{Al}_{2} \mathrm{O}_{3}$ support). For comparison it has been also included the catalytic results for samples $4 \mathrm{AC}$ and $8 \mathrm{AC}$.

Acknowledgments: The authors would like to acknowledge the DGICYT (CTQ2015-68951-C3-1-R and MAT2017-84118-C2-1-R projects), the Secretary of State for International Cooperation in Spain (Project AP/040992/11) and FEDER for financial support. B.S. also thanks the University of Valencia (UV-INV-AE16-484416).

Author Contributions: S.B. carried out the catalytic tests and participated in the discussion of the results; A.M. prepared some catalysts and participated in the discussion of the results; B.S. participated in the discussion of the results, in the writing of the paper and is the main responsible for the characterization part; R.I. actively participated in the discussion of the results; and J.M.L.N. conceived the experiments and is the coordinator of the work.

Conflicts of Interest: The authors declare no conflict of interest.

\section{References}

1. Chieregato, A.; López Nieto, J.M.; Cavani, F. Mixed oxides catalysts with vanadium as the key element for gas phase reactions. Coord. Chem. Rev. 2015, 301-302, 3-23. [CrossRef]

2. López Nieto, J.M. Selective oxidative activation of light alkanes. From supported vanadia to multicomponent bulk V-containing catalysts. Top. Catal. 2006, 41, 3-15. [CrossRef]

3. Wachs, I.E. Catalysis science of supported vanadium oxide catalysts. Dalton Trans. 2013, 42, 11762-11769. [CrossRef] [PubMed]

4. James, O.O.; Mandal, S.; Alele, N.; Chowdhury, B.; Maity, S. Lower alkanes dehydrogenation: Strategies and reaction routes to corresponding alkenes. Fuel Process. Technol. 2016, 149, 239-255. [CrossRef]

5. Blasco, T.; López Nieto, J.M. Oxidative dehydrogenation of short chain alkanes on supported vanadium oxide catalysts. Appl. Catal. A Gen. 1997, 157, 117-142. [CrossRef]

6. Kung, H.H.; Kung, M.C. Oxidative dehydrogenation of alkanes over vanadium-magnesium-oxides. Appl. Catal. A Gen. 1997, 157, 105-116. [CrossRef]

7. Cavani, F.; Trifiró, F. Some aspects that affect the selective oxidation of paraffins. Catal. Today 1997, 36, 431-439. [CrossRef]

8. Banares, M.A. Supported metal oxide and other catalysts for ethane conversion: A review. Catal. Today 1999, 51,319-348. [CrossRef]

9. Bhasin, M.M.; McCain, J.H.; Vora, B.V.; Imai, T.; Pujado, P.R. Dehydrogenation and oxydehydrogenation of paraffins to olefins. Appl. Catal. A Gen. 2001, 221, 397-419. [CrossRef]

10. Cavani, F.; Ballarini, N.; Cericola, A. Oxidative dehydrogenation of ethane and propane. How far from commercial implementation? Catal. Today 2007, 127, 113-131. [CrossRef]

11. Gartner, C.A.; Van Veen, A.C.; Lercher, J.A. Oxidative dehydrogenation of ethane: Common principles and mechanistic aspects. Chem CatChem 2013, 5, 3196-3217. [CrossRef]

12. Galli, A.; Lopez Nieto, J.M.; Dejoz, A.; Vazquez, M.I. The effect of potassium on the selective oxidation of n-butane and ethane over $\mathrm{Al}_{2} \mathrm{O}_{3}$-supported vanadia catalysts. Catal. Lett. 1995, 34, 51-58. [CrossRef] 
13. Argyle, M.D.; Chen, K.; Bell, A.T.; Iglesia, E. Ethane oxidative dehydrogenation pathways on vanadium oxide catalysts. J. Phys. Chem. B 2002, 106, 5421-5427. [CrossRef]

14. Dinse, A.; Ozarowski, A.; Hess, Ch.; Schomacker, R.; Dinse, K.P. Potential of high frequency EPR for investigation of supported vanadium oxide. J. Phys. Chem. C 2008, 112, 17664-17671. [CrossRef]

15. Chen, K.D.; Bell, A.T.; Iglesia, E. The relationship between the electronic and redox properties of dispersed metal oxides and their turnover rates in oxidative dehydrogenation reactions. J. Catal. 2002, 209, 35-42. [CrossRef]

16. Lopez Nieto, J.M.; Soler, J.; Concepcion, P.; Herguido, J.; Menendez, M.; Santamaria, J. Oxidative dehydrogenation of alkanes over V-based catalysts: Influence of redox properties on catalytic performance. J. Catal. 1999, 185, 324-332. [CrossRef]

17. Argyle, M.D.; Chen, K.; Iglesia, E.; Bell, A.T. In situ UV-visible spectroscopic measurement of kinetic parameters and active sites for catalytic oxidation of alkanes on vanadium oxides. J. Phys. Chem. B 2005, 109, 2414-2420. [CrossRef] [PubMed]

18. Chen, K.; Khodakov, A.; Yang, J.; Bell, A.T.; Iglesia, E. Isotopic tracer kinetic studies of oxidative dehydrogenation pathways on vanadium oxide catalysts. J. Catal. 1999, 186, 325-333. [CrossRef]

19. Mul, G.; Banares, M.A.; Garcia Cortez, G.; Linden, B.; Khatib, S.J.; Moulijn, J.A. Multitrack and operando Raman G-C study of oxidative dehydrogenation of propane over alumina-supported vanadium oxide catalysts. Phys. Chem. Chem. Phys. 2003, 5, 4378-4383. [CrossRef]

20. Olthof, B.; Khodakov, A.; Bell, A.T.; Iglesia, E. Effects of support composition and pretreatment conditions on the structure of vanadia dispersed on $\mathrm{SiO}_{2}, \mathrm{Al}_{2} \mathrm{O}_{3}, \mathrm{TiO}_{2}, \mathrm{ZrO}_{2}$ and $\mathrm{HfO}_{2}$. J. Phys. Chem. B 2000, 104, 1516-1528. [CrossRef]

21. Blasco, T.; Galli, A.; Lopez Nieto, J.M.; Trifiro, F. Oxidative dehydrogenation of ethane and n-butane on $\mathrm{VOx} / \mathrm{Al}_{2} \mathrm{O}_{3}$ catalysts. J. Catal. 1997, 169, 203-211. [CrossRef]

22. Lin, X.; Hoel, C.A.; Sachtler, W.M.H.; Poeppelmeier, K.R.; Weitz, E. Oxidative dehydrogenation (ODH) of ethane with $\mathrm{O}_{2}$ as oxidant on selected transition metal-loaded zeolites. J. Catal. 2009, 265, 54-62. [CrossRef]

23. Al-Ghamdi, S.A.; De Lasa, H. Propylene production via propane oxidative dehydrogenation over $\mathrm{VOx} / \gamma-\mathrm{Al}_{2} \mathrm{O}_{3}$ catalyst. Fuel 2014, 128, 120-140. [CrossRef]

24. Solsona, B.; Dejoz, A.; Garcia, T.; Concepción, P.; Lopez Nieto, J.M.; Vázquez, M.I.; Navarro, M.T. Molybdenum-vanadium supported on mesoporous alumina catalysts for the oxidative dehydrogenation of ethane. Catal. Today 2006, 117, 228-233. [CrossRef]

25. Chen, S.; Ma, F.; Xu, A.; Wang, L.; Chen, F.; Lu, W. Study on the structure, acidic properties of V-Zr nanocrystal catalysts in the oxidative dehydrogenation of propane. Appl. Surf. Sci. 2014, 289, 316-325. [CrossRef]

26. Elbadawi, A.H.; Ba-Shammakh, M.S.; Al-Ghamdi, S.; Razzak, S.A.; Hossain, M.M. Reduction kinetics and catalytic activity of $\mathrm{VOx} / \gamma-\mathrm{Al}_{2} \mathrm{O}_{3}-\mathrm{ZrO}_{2}$ for gas phase oxygen free ODH of ethane. Chem. Eng. J. 2016, 284, 448-457. [CrossRef]

27. Rostom, S.; de Lasa, H. Propane Oxidative Dehydrogenation Using Consecutive Feed Injections and Fluidizable $\mathrm{VOx} / \gamma \mathrm{Al}_{2} \mathrm{O}_{3}$ and $\mathrm{VOx} / \mathrm{ZrO}_{2}-\gamma \mathrm{Al}_{2} \mathrm{O}_{3}$ Catalysts. Ind. Eng. Chem. Res. 2017, 56, 13109-13124. [CrossRef]

28. Heracleous, E.; Lemonidou, A.A. $\mathrm{Ni}-\mathrm{Nb}-\mathrm{O}$ Mixed Oxides as Highly Active and Selective Catalysts for Ethene Production via Ethane Oxidative Dehydrogenation. Part I: Characterization and Catalytic Performance. J. Catal. 2006, 237, 162-174. [CrossRef]

29. Skoufa, Z.; Heracleous, E.; Lemonidou, A.A. Mechanism and Nature of Active Sites over NiO-Based Catalysts via Isotopic Labeling and Methanol Sorption Studies. J. Catal. 2015, 322, 118-129. [CrossRef]

30. Ipsakis, D.; Heracleous, E.; Silvester, L.; Bukur, D.B.; Lemonidou, A.A. Reduction and Oxidation Kinetic Modeling of NiO-based Oxygen Transfer Materials. Chem. Eng. J. 2017, 308, 840-852. [CrossRef]

31. Delgado, D.; Solsona, B.; Ykrelef, A.; Rodriguez-Gomez, A.; Caballero, A.; Rodriguez-Aguado, E.; Rodriguez-Castellon, E.; Lopez Nieto, J.M. Redox and Catalytic Properties of Promoted NiO Catalysts for the Oxidative Dehydrogenation of Ethane. J. Phys. Chem. C 2017, 121, 25132-25142. [CrossRef]

32. Solsona, B.; Concepcion, P.; Lopez Nieto, J.M.; Dejoz, A.; Cecilia, J.A.; Agouram, S.; Soriano, M.D.; Torres, V.; Jimenez-Jimenez, J.; Rodriguez Castellon, E. Nickel Oxide Supported on Porous Clay Heterostructures as Selective Catalysts for the Oxidative Dehydrogenation of Ethane. Catal. Sci. Technol. 2016, 6, 3419-3429. [CrossRef] 
33. Lopez Nieto, J.M.; Botella, P.; Vazquez, M.I.; Dejoz, A. The selective Oxidative Dehydrogenation of Ethane over Hydrothermally Synthesized MoVTeNb Catalysts. Chem. Commun. 2002, 1906-1907. [CrossRef]

34. Lopez Nieto, J.M.; Botella, P.; Vazquez, M.I.; Dejoz, A. Method for the Oxidative Dehydrogenation of Ethane. US Patent 7,319,179 B2, 15 January 2008.

35. Gartnet, C.; Van Veen, A.C.; Lercher, J.A. Oxidative Dehydrogenation of Ethane on Dynamically Rearranging Supported Chloride Catalysts. J. Am. Chem. Soc. 2014, 136, 12691-12701. [CrossRef] [PubMed]

36. Tatibouet, J.M. Methanol oxidation as a catalytic surface probe. Appl. Catal. A Gen. 1997, 148, $213-252$. [CrossRef]

37. Forzatti, P.; Tronconi, E.; Elmi, A.S.; Busca, G. Methanol oxidation over vanadia-based catalysts. Appl. Catal. A Gen. 1997, 157, 387-408. [CrossRef]

38. Wachs, I.E.; Chen, Y.; Jehng, J.M.; Briand, L.E.; Tanaka, T. Molecular structure and reactivity of the group V metal oxides. Catal. Today 2003, 78, 13-24. [CrossRef]

39. Shah, P.R.; Baldychev, I.; Vohs, J.M.; Gorte, R.J. Comparison of redox isotherms for vanadia supported on zirconia and titania. Appl. Catal. A Gen. 2009, 361, 13-17. [CrossRef]

40. Baldychev, I.; Gorte, R.J.; Vohs, J.M. The impact of redox properties on the reactivity of $\mathrm{V}_{2} \mathrm{O}_{5} / \mathrm{Al}_{2} \mathrm{O}_{3}$ catalysts. J. Catal. 2010, 269, 397-403. [CrossRef]

41. Hess, C. Nanostructured vanadium oxide model catalysts for selective oxidation reactions. Chem. Phys. Chem. 2009, 10, 319-326. [CrossRef] [PubMed]

42. Smith, M.A.; Zoelle, A.; Yang, Y.; Rioux, R.M.; Hamilton, N.G.; Amakawa, K.; Nielsen, P.K.; Trunschke, A. Surface roughness effects in the catalytic behavior of vanadia supported on SBA-15. J. Catal. 2014, 312, 170-178. [CrossRef]

43. Wang, N.L.; Qiu, J.E.; Wu, J.; You, K.Y.; Luo, H.A. A comparison of the redox properties of bulk vanadium mixed oxide catalysts. Catal. Lett. 2015, 145, 1792-1797. [CrossRef]

44. Beck, B.; Harth, M.; Hamilton, N.G.; Carrero, C.; Uhlrich, J.J.; Trunschke, A.; Shaikhutdinov, S.; Schubert, H.; Freund, H.J.; Schlögl, R.; et al. Partial oxidation of ethanol on vanadia catalysts on supporting oxides with different redox properties compare to propane. J. Catal. 2012, 296, 120-131. [CrossRef]

45. Kim, T.; Wachs, I.E. $\mathrm{CH}_{3} \mathrm{OH}$ oxidation over well-defined supported $\mathrm{V}_{2} \mathrm{O}_{5} / \mathrm{Al}_{2} \mathrm{O}_{3}$ catalysts. Influence of vanadium oxide loading and surface vanadium-oxygen functionalities. J. Catal. 2008, 255, 197-205. [CrossRef]

46. Baldychev, I.; Vohs, J.M.; Gorte, R.J. The effect of support on redox properties and methanol-oxidation activity of vanadia catalysts. Appl. Catal. A Gen. 2011, 391, 86-91. [CrossRef]

47. Soriano, M.D.; Chieregato, A.; Zamora, S.; Basile, F.; Cavani, F.; López Nieto, J.M. Promoted hexagonal tungsten bronzes as selective catalysts in the aerobic transformation of alcohols: Glycerol and methanol. Top. Catal. 2016, 59, 178-185. [CrossRef]

48. $\mathrm{Hu}, \mathrm{F} . ; \mathrm{Wu}, \mathrm{X}$.; Wanga, Y.; Lai, X. Ultrathin $\gamma-\mathrm{Al}_{2} \mathrm{O}_{3}$ nanofibers with large specific surface area and their enhanced thermal stability by Si-doping. RSC Adv. 2015, 5, 54053-54058. [CrossRef]

49. Zang, F.; Chupas, P.J.; Lui, S.L.A.; Hanson, J.C.; Caliebe, W.A.; Lee, P.L.; Chan, S.W. In situ study in the crystallization from amorphous to cubic zirconium oxide: Rietveld and reverse Monte Carlo Analyses. Chem. Mater. 2007, 19, 3118-3126. [CrossRef]

50. Pieck, C.L.; Del Val, S.; Lopez Granados, M.; Banares, M.A.; Fierro, J.L.G. Bulk and Surface structures of $\mathrm{V}_{2} \mathrm{O}_{5} / \mathrm{ZrO}_{2}$ systems and their relevance for o-xylene oxidation. Langmuir 2002, 18, 2642-2648. [CrossRef]

51. Soriano, M.D.; Rodríguez-Castellón, E.; García-González, E.; López Nieto, J.M. Catalytic behavior of $\mathrm{NaV}_{6} \mathrm{O}_{15}$ bronze for partial oxidation of hydrogen sulfide. Catal. Today 2014, 238, 62-68. [CrossRef]

52. Zhao, C.; Wachs, I.E. Selective oxidation of propylene over model supported $\mathrm{V}_{2} \mathrm{O}_{5}$ catalysts. Influence of surface coverage and oxide support. J. Catal. 2008, 257, 181-189. [CrossRef]

53. Martinez-Huerta, M.V.; Gao, X.; Tian, H.; Wachs, I.E.; Fierro, J.L.G.; Banares, M.A. Oxidative dehydrogenation of ethane to ethylene over alumina-supported vanadium oxide catalysts. Relationship between molecular structure and chemical reactivity. Catal. Today 2006, 118, 279-287. [CrossRef]

54. Khodakov, A.; Yang, J.; Su, S.; Iglesia, E.; Bell, A.T. Structure and properties of vanadium oxide-zirconia catalysts for propane oxidative dehydrogenation. J. Catal. 1998, 177, 343-351. [CrossRef]

55. Kanervo, J.M.; Harlin, M.E.; Krause, A.O.I.; Bañares, M.A. Characterisation of alumina-supported vanadium oxide catalysts by kinetic analysis of $\mathrm{H}_{2}$-TPR data. Catal. Today 2003, 78, 171-180. [CrossRef] 
56. Deo, G.; Wachs, I.E. Reactivity of supported vanadium oxide Catalysts: The partial oxidation of methanol. J. Catal. 1994, 146, 232-334. [CrossRef]

57. Gao, X.; Banares, M.A.; Wachs, I.E. Ethane and n-butane oxidation over supported vanadium oxide catalysts: An in situ UV-visible diffuse reflectance spectroscopic investigation. J. Catal. 1999, 188, 325-331. [CrossRef]

58. Silversmit, G.; Depla, D.; Poelman, H.; Marin, G.B.; De Gryse, R. Determination of the V2p XPS binding energies for different vanadium oxidation states $\left(\mathrm{V}^{5+}\right.$ to $\left.\mathrm{V}^{0+}\right)$. J. Electron. Spectrosc. 2004, 135, 167-175. [CrossRef]

59. Hess, C.; Tzolova-Müller, G.; Herbert, R. The influence of water on the dispersion of vanadia supported on silica SBA-15, a combined XPS and Raman study. J. Phys. Chem. C 2007, 111, 9471-9479. [CrossRef]

60. Chen, K.; Bell, A.T.; Iglesia, E. Kinetics and mechanism of oxidative dehydrogenation of propane on vanadium, molybdenum and tungsten oxides. J. Phys. Chem. B 2000, 104, 1292-1299. [CrossRef]

61. Elbadawi, A.H.; Ba-Shammakh, M.S.; Al-Ghamdi, S.; Razzak, S.A.; Hossain, M.M.; de Lasa, H.I. A fluidizable $\mathrm{VOx} / \gamma-\mathrm{Al}_{2} \mathrm{O}_{3}-\mathrm{ZrO}_{2}$ catalyst for the $\mathrm{ODH}$ of ethane to ethylene operating in a gas phase oxygen free environment. Chem. Eng. Sci. 2016, 145, 59-70. [CrossRef]

62. Solsona, B.; Blasco, T.; Lopez Nieto, J.M.; Peña, M.L.; Rey, F.; Vidal Moya, A. Vanadium oxide supported on mesoporous MCM-41 as selective catalysts in the oxidative dehydrogenation of alkanes. J. Catal. 2001, 203, 443-452. [CrossRef]

(C) 2018 by the authors. Licensee MDPI, Basel, Switzerland. This article is an open access article distributed under the terms and conditions of the Creative Commons Attribution (CC BY) license (http://creativecommons.org/licenses/by/4.0/). 